\title{
Earnings Management around the Tax Cuts and Jobs Act of 2017
}

\begin{abstract}
This paper examines earnings management around the reduction in the corporate tax rate from $35 \%$ to $21 \%$ as enacted by the Tax Cuts and Jobs Act (TCJA) of 2017. Building on a theoretical model that considers a higher level of book-tax conformity of 'real earnings management' (REM) relative to 'accrual-based earnings management' (AEM), we hypothesize that firms concertedly use these manipulation techniques for different purposes. Specifically, we predict and find that firms engage in REM to reduce income in the high-tax period prior to the TCJA. Our results suggest that the 851 firms of our sample save approximately $\$ 32$ billion in taxes from REM shifting. We also predict and find that firms use AEM, which has a lower degree of book-tax conformity, to simultaneously increase book income. Consistent with intertemporal income shifting, we find that these effects reverse in 2018. Overall, our results document an unintended consequence of the TCJA on firm behavior that should be of interest to policymakers, regulators, and researchers as they evaluate the largest tax reform since 1986.
\end{abstract}

Keywords: Tax Cuts and Jobs Act (TCJA); tax reform; income shifting; tax avoidance; real earnings management; accrual-based earnings management.

JEL Codes: $\quad$ G12; G14; H25; M41; M48. 


\section{INTRODUCTION}

This paper examines earnings management around the 'Tax Cuts and Jobs Act' (TCJA) of 2017. One of the major changes of the TCJA is the reduction of the federal tax rate from $35 \%$ to $21 \%$. This reduction creates incentives to shift taxable income from the high-tax period prior to the TCJA (i.e., the period with a tax rate of 35\%) to the low-tax period after the TCJA (i.e., the period with a tax rate of $21 \%$ ). However, to the extent decreases in taxable income also lower book income there are potential financial reporting costs to shifting income (Shackelford and Shevlin 2001). We investigate if the difference in book-tax conformity between 'real earnings management' (REM) versus 'accrual-based earnings management' (AEM) affects the behavior of firms surrounding the TCJA. Based on a theoretical model that incorporates a higher level of book-tax conformity of REM relative to AEM (Zang 2012), we predict that firms use REM to decrease taxable income prior to the TCJA and simultaneously take advantage of the relatively lower book-tax conformity of AEM to manage book income higher to offset the reduction of book income due to REM. ${ }^{1}$

This study contributes to both the earnings management and tax literature. Prior earnings management research suggests that REM and AEM serve as substitutes (Ewert and Wagenhofer 2005; Zang 2012). In contrast, we argue that due to differences in book-tax conformity REM and AEM can serve as negative complements when managers react to a tax rate change. This study also contributes to tax literature on income shifting by examining the effects of book-tax conformity on intertemporal income shifting. Furthermore, the majority of the prior tax literature examines cross-sectional income shifting from high-tax to low-tax countries (e.g., Collins, Kemsley, and Lang 1998; Huizinga and Laeven 2008; Klassen and Laplante 2012). In contrast, there is relatively little evidence on intertemporal income shifting. The few studies on

\footnotetext{
${ }^{1}$ We define book-tax conformity as the positive association of changes in book income with simultaneous changes in tax income. For example, when a firm increases book income by cutting R\&D expenses, the firm (generally) also simultaneously increases taxable income (Zang 2012). This baseline definition is consistent with the literature on book-tax differences (Desai and Dharmapala 2006).
} 
intertemporal income shifting do not incorporate book-tax conformity and suggest that firms use multiple methods of earnings management to reduce taxable income in high-tax periods (Scholes, Wilson, and Wolfson 1992). We explicitly consider the link between book and tax accounts and analyze whether different levels of book-tax conformity of REM and AEM affect their use around a major tax rate change. Furthermore, our estimates of the tax revenue lost due to income shifting via REM and increase in book income due to AEM provide policymakers and regulators with insights into how firms respond to a major tax rate cut.

We develop our hypotheses using a simple theoretical model that allows firms to manipulate income through both REM and AEM around a tax rate decrease. The distinction between these manipulation techniques is that REM directly affects cash flows while AEM does not. Because the US tax system recognizes income and deductions using a modified cash basis of accounting, we follow prior literature and posit that REM has a higher degree of book-tax conformity than AEM (Zang 2012). A key insight of the model is that firms always use REM to reduce taxable income in the high-tax period. However, due to the high book-tax conformity of REM, this manipulation also decreases book income. Our model predicts that firms use AEM to offset this reduction in book income. Specifically, when a firm would miss an earnings target after REM but before AEM, the firm offsets REM using upwards AEM to meet/beat this earnings target without increasing taxable income.

To illustrate the predicted behavior, Appendix A provides a numerical example of how both REM and AEM can be used to reduce taxable income and simultaneously meet an earnings target around a corporate tax rate decrease from $35 \%$ in 2017 to $21 \%$ in 2018 . In both periods, the firm earns $\$ 500$ of unmanaged pre-tax income in the tax and the book accounts. In 2017 , the firm seeks to reduce taxable income by $\$ 100$ to $\$ 400$ to lower tax burdens but still wants to report $\$ 500$ of book income. To reduce taxable income, the firm accelerates advertising expenses from 2018 to 2017 (i.e., REM with full book-tax conformity) and delays an asset impairment (i.e., AEM with zero book-tax conformity) from 2017 to 2018. The firm 
simultaneously reaches the objective to lower tax expenses while still meeting the earnings target in the book accounts.

The corporate tax rate cut of the TCJA provides an excellent setting to test our predictions for at least two reasons. First, the tax rate cut is a large and plausibly exogenous shock to the earnings management incentives of firms. In theory, firms should be engaging in a baseline amount of REM and AEM around year-ends. However, in order to develop an internally valid test of these predicted effects, we need to observe a tax rate change and subsequent change in firm behavior. The tax rate cut from $35 \%$ to $21 \%$ is a two-fifths reduction in the corporate tax rate representing the largest percentage rate reduction in the history of the US corporate tax. This provides a strong shock to the earnings management incentives of firms to test for our predicted effects.

Second, the timing of the introduction and passage of the TCJA creates a tight treatment window to observe potential effects on firm behavior. Unlike prior tax reforms such as the 1986 Tax Reform Act, the TCJA was introduced and passed quickly without significant debate or public input (Slemrod 2018). Furthermore, although momentum for tax reform began with the election of President Trump in 2016, the passage of the TCJA was far from certain until late in November of 2017 (Gaertner, Hoopes, and Williams 2020) providing firms with a relatively short window to react to the corporate tax rate cut. This allows us to isolate the time interval when we expect firms to engage in REM and AEM activities.

To test our predictions, we use quarterly data from 2010 to 2019 . In line with the prior literature on tradeoffs between REM and AEM, we measure REM as abnormal production costs less abnormal discretionary expenses and AEM as discretionary accruals (e.g., Zang 2012). We include firm, calendar quarter and fiscal quarter fixed effects to control for time invariant firm and quarter characteristics and control for the costs related to REM and AEM. In our primary analyses, we examine earnings management in the four quarters prior to the effectiveness of the TCJA (i.e., $1^{\text {st }}$ to $4^{\text {th }}$ quarter of 2017 for a calendar year end firm; 'expect interval'). We argue 
that if firms are managing earnings around the TCJA tax cut we will observe a reversal of AEM - and perhaps also of REM - in the subsequent four quarters (i.e., $1^{\text {st }}$ to $4^{\text {th }}$ quarter of 2018 for a calendar year end firm), denoted as the 'effective interval'. To improve the internal validity of our results, we also use tighter intervals of two quarters (i.e., the final two quarters of 2017 and the first two quarters of 2018) to study the effects that are concentrated in the quarters when the corporate tax rate cut became certain.

Our empirical results are consistent with our theoretical model and predictions. We find that firms use REM to decrease taxable income in the high-tax period prior to the TCJA. We estimate a reduction of tax payments through REM of about $\$ 37.5$ million per firm and aggregated tax savings of roughly $\$ 31.9$ billion for the 851 firms in our sample. We also find that firms offset this decrease in book income due to REM with an increase in book income through AEM in the high-tax period. This increase in book income via AEM is reversed in the subsequent low-tax period. These results are concentrated in the final two quarters of 2017 and in the first two quarters of 2018, which is consistent with intertemporal income shifting immediately prior to and after the TCJA was passed. We corroborate these results using pseudoevent dates where the results weaken the more we shift away from the correct treatment date. Our conclusions are also robust for subsamples where we control for other TCJA provisions and for alternative specifications of our REM and AEM measures. Taken together, our results suggest that firms react to the corporate tax rate cut by engaging in REM to decrease taxable income while engaging in AEM to offset the corresponding decrease in book income.

We also examine the techniques used to shift income and cross-sectional variation in the incentives to engage in offsetting AEM. Consistent with our theory, we find that the AEM is concentrated in non-current accruals, which have lower book-tax conformity than current accruals (Guenther 1994). We also find the results for AEM are strongest for firms that face financial reporting pressure. We find that firms use all of the REM strategies of overproduction, increasing R\&D expenses, and boosting selling, general, and administrative expenses (SG\&A) 
to lower taxable income in the high-tax period. Finally, we find our results are robust to using only domestic firms, omitting firms with large deferred tax balances, and eliminating loss firms, which alleviates concerns that other TCJA provisions and effects explain our results. We also find evidence that some firms engage in earnings management to create net operating losses in 2017 that can be carried back to 2016 to generate tax refunds. Overall, these results allow us to attribute the observed changes in firm behavior to the change in the tax rate and shed light on how firms shift income around a decrease in the corporate tax rate.

This study makes the following contributions to the literature. First, our findings indicate that the tax planning of the firm around a major tax rate cut is just one piece in the complex puzzle of firms' earnings management incentives. We expand the prior literature on inherent trade-offs between tax planning decisions and financial reporting costs (Shackelford and Shevlin 2001) and document that firms can use REM and AEM to simultaneously reach both tax and book income targets. These findings suggest that firms do not always sacrifice book income to manage taxable income downward in order to avoid taxes.

Second, we add to the literature on earnings management. While the prior literature suggests REM and AEM are used as substitutes to reach reporting targets (e.g., Roychowdhury 2006; Zang 2012), our findings indicate that firms use REM and AEM for different purposes around tax rate changes. Due to the generally lower book-tax conformity of AEM relative to REM, we find that firms use REM to lower taxable income in high-tax periods and simultaneously use AEM to offset the reduction in book income. This suggests that REM and AEM act as negative complements when there is a shock to the tax incentives of the firm.

Third, we add to the evaluation of the consequences of the TCJA (e.g., Dharmapala 2018; Koutney and Mills 2018; Gale, Gelfond, Krupkin, Mazur, and Toder 2019; Gaertner et al. 2020; Carrizosa, Gaertner, and Lynch 2020). Specifically, we document an unintended consequence of the TCJA in firms changing operating decisions and manipulating accruals around the tax rate change. Importantly, the Congressional Budget Office (CBO) estimates of 
the effects of the TCJA on tax collections do not consider the effects of tax rate changes on intertemporal income shifting (CBO 2018). Our results suggest that firms managed earnings to avoid approximately $\$ 32$ billion in corporate taxes, which represents more than 10 percent of 2017 corporate tax collections ( $\$ 297$ billion). Our findings suggest that policymakers should carefully consider the costs and benefits of tax rate reduction. Regulators such as the 'Internal Revenue Service' (IRS) and the 'Securities and Exchange Commission' (SEC) will be interested in our findings as they illustrate context-specific earnings management to avoid taxes and to meet book earnings targets.

Our findings are subject to several caveats. First, due to the archival nature of our data, we cannot establish causal inference. Although the timing and magnitude of the tax rate cut of the TCJA generate a plausibly exogenous shock to the incentives of firms and our fixed effects strategy controls for time-invariant firm characteristics, we cannot completely rule out endogeneity concerns. Second, we rely on data from GAAP-based financial statements as data from tax accounts are unavailable precluding us from examining the effects of REM and AEM in specific tax return accounts. Finally, we focus on the decrease of the federal tax rate as the key component of the TCJA. However, the TCJA contains several other tax provision changes. Consequently, we cannot ultimately rule out that our findings are driven by other changes in the US tax regime. Although many of these changes did not take effect until 2018 potentially alleviating concerns of other provisions affecting our results. Despite these limitations, we believe that we make a significant contribution to the literature by documenting an economically significant unintended consequence of the largest tax rate change since 1986.

\section{PRIOR LITERATURE}

\section{Income Shifting to Reduce Taxes}

Prior research suggests that firms use differences in tax regimes to avoid taxes through income shifting (Shackelford and Shevlin 2001; Hanlon and Heitzman 2010). Most of these studies refer to cross-sectional income shifting, i.e., the use of heterogeneity in tax jurisdictions 
to reduce tax burdens (e.g., Collins et al. 1998; Huizinga and Laeven 2008; Huizinga, Laeven, and Nicodeme 2008; De Simone 2016). In contrast, there are few studies that examine how taxes affect intertemporal income shifting. The most prominent example is research surrounding the 'Tax Reform Act' (TRA) of 1986 (e.g., Guenther 1994; Maydew 1997; Shane and Stock 2006). For example, Scholes et al. (1992) document income shifting behavior around the anticipated reduction of tax rates by the TRA. They show that firms defer book gross margins and accelerate book SG\&A expenses to shift taxable income from the periods prior to the effectiveness of the TRA to later low-tax periods. This prior research generally assumes full book-tax conformity. ${ }^{2}$

This study contributes to this literature by examining how the book-tax conformity of the different forms of earnings management affect intertemporal income shifting. Specifically, we examine whether firms use downwards REM and its specific components of underproduction, abnormally high $\mathrm{R} \& \mathrm{D}$, and abnormally high SG\&A activities to decrease taxable income in the high-tax period prior to TCJA enactment and AEM and its components of current versus non-current accruals to offset the corresponding decrease in book income.

\section{Trade-Off between Book and Tax Earnings Management}

There is a "natural" trade-off between tax planning and firms' efforts to minimize real and accounting non-tax costs (Scholes and Wolfson 1992). For example, assuming a certain degree of book-tax conformity, incentives to lower taxes often stand vis-à-vis financial reporting incentives (Shackelford and Shevlin 2001). When firms engage in tax planning that decreases taxable income there is often a corresponding decrease in book income. Additionally, using income-increasing earnings management to meet/beat earnings targets also increases taxable income, leading to higher taxes.

\footnotetext{
${ }^{2}$ Lopez, Regier, and Lee (1998) provide further evidence for earnings management around the TRA and that these manipulations are more pronounced for tax aggressive firms. Intertemporal income shifting for different purposes is also documented for non-US settings (e.g., Lin, Lu, and Zhang 2012; Andries, Cools, and van Uytbergen 2017).
} 
Prior literature examines trade-offs between tax and reporting incentives for specific accounts. Around the TRA, Maydew (1997) investigates tax-induced intertemporal income shifting by firms with net operating loss carry backs and provides evidence that the tax and nontax costs and benefits of the manipulation of taxable income determine the extent of the shifting. Matsunaga, Shevlin, and Shores (1992) show that some firms forego net tax benefits by not undertaking disqualifying dispositions of incentive stock options in order to avoid reductions in reported earnings. ${ }^{3}$ Guenther, Maydew, and Nutter (1997) finds that firms use current accruals to shift taxable income from the high-tax rate period to the low-tax rate period around TRA. However, prior literature does not consider the differences in book-tax conformity of REM and AEM around a tax rate change. Our study seeks to fill this gap in the literature by leveraging the differences in the book-tax conformity of REM and AEM.

The U.S. tax system recognizes income and deductions using a modified cash basis of accounting (IRS Publication 538). Given that REM directly influences cash flows, e.g., lower cash outflows when cutting discretionary expenses (Cohen, Dey, and Lys 2008), while AEM does not, we postulate a higher level of book-tax conformity of REM relative to AEM (Zang 2012). These differences in book-tax conformity suggest that the non-tax financial reporting costs of REM versus AEM will lead to the use of specific techniques to shift taxable and book income around a major tax rate change.

\section{HYPOTHESES}

We begin our hypotheses development with a theoretical model to illustrate the decisions managers face when the corporate tax rate is reduced. Building on the prior theoretical (Ewert and Wagenhofer 2005; Randolph, Salamon, and Seida 2005) and empirical literature (Matsunaga et al. 1992; Zang 2012), we posit the following presumptions.

\footnotetext{
${ }^{3}$ Other examples for such trade-offs are related to the adoption (Cushing and LeClere 1992) and abandonment of the last-in-first-out method (Johnson and Dhaliwal 1988) and to bank's securities transactions (Scholes, Wilson, and Wolfson 1990). Further, several studies examine the intertemporal income shifting of firms subject to the 1986 alternative minimum tax (e.g., Boynton, Dobbins, and Plesko 1992; Dhaliwal and Wang 1992).
} 
Step (i): Setting of the model. We postulate that a firm exists for two periods: $t=\{1,2\}$.

The corporate tax rates $\left(\tau_{t}\right)$ in these periods are $\tau_{1}$ and $\tau_{2}$ while an exogenous decrease of the corporate tax rate occurs $\left(\tau_{1}>\tau_{2}\right){ }^{4}$

Step (ii): Earnings management techniques. We consider that firms can use both REM and AEM to manipulate both book and taxable income. ${ }^{5}$ We define $m_{r}$ and $m_{a}$ as incomeincreasing REM and AEM, respectively. REM and AEM have different costs (Zang 2012). For simplicity, we follow Ewert and Wagenhofer (2005) and assume that REM, which is a deviation from optimal business practices $\left(\left|m_{r}\right|>0\right)$, induces economic costs $\left(c_{r}\left(m_{r}\right)\right)$ (Vorst 2016) while AEM does not. ${ }^{6}$ We transfer these assumptions into a convex cost function of REM which increases with the extent of the deviation. This presumption can be interpreted as a generalized case of a u-shape-type function which is often applied in the prior literature (e.g., Ewert and Wagenhofer 2005). We formalize these assumptions about the REM cost function as follows:

$$
\begin{gathered}
c^{\prime}{ }_{r}\left(m_{r}\right)=\partial c_{r}\left(m_{r}\right) / \partial m_{r} \\
c^{\prime}{ }_{r}\left(m_{r}\right)<0 \forall m_{r}<0, \quad c^{\prime}{ }_{r}\left(m_{r}\right) \geq 0 \forall m_{r} \geq 0, \quad \text { and } \quad c^{\prime \prime}{ }_{r}\left(m_{r}\right)>0
\end{gathered}
$$

Further, we assume that REM and AEM in $t=1$ fully reverse in $t=2 .{ }^{7}$

\footnotetext{
${ }^{4}$ For simplicity, profits and losses in the tax accounts in $t=0$ are treated symmetrically. This assumption implies that the firm receives a full tax refund in $t=1$ if the taxable income in $t=0$ is negative, thus it can be interpreted as a gain in present value because of future use of the tax loss carry forward. The TCJA imposed new regulations limiting the deductibility for net operating losses to $80 \%$ in future years. Sensitivity analyses suggest that our results hold if we omit loss observations.

${ }^{5}$ Consistent with the prior literature (Roychowdhury 2006; Kanodia and Sapra 2016), we define REM as a deviation from normal business practices, i.e., changes in the amount, timing, and/or structure of transactions, to manipulate income (e.g., reduction of research and development (R\&D) activities; for further examples see Cohen et al. 2008). We define AEM as a manipulation of income through changes in accounting methods and/or estimates (e.g., changes in the depreciation method of fixed assets).

${ }^{6}$ To provide descriptive evidence for this assumption in our setting from 2010 to 2019 , we study the association of REM and AEM with future operating profitability $\left(R O A_{i t+\tau}\right)$. Supporting our assumptions about the costs of REM and the negligible costs of AEM, we find a negative association of unsigned $R E M_{i t}$ and $R O A_{i t+\tau}$ for time lags $(\tau)$ until the end of the fiscal year after the next. In contrast, we do not find significant associations of unsigned $A E M_{i t}$ and $R O A_{i t+\tau}$ for any subsequent fiscal quarter. We acknowledge AEM is not costless and can induce other non-economic costs such as an increase in risk.

${ }^{7}$ In our two-period setting, AEM in $t=0$ reverses in the subsequent period $(t=1)$ due to natural reversals of accruals (Dechow and Dichev 2002). In contrast, there is no mechanical reversal of REM because REM is always an intentional decision of the management and sometimes only partial reversals are possible (Vorst 2016; Ernstberger, Link, Stich, and Vogler 2017). However, we argue that firms may move up certain activities to the earlier high-tax period (e.g., earlier advertising efforts) that reverse in the later low-tax period. Further, firms may wish to promptly return to optimal business practices after incoming-decreasing REM in the earlier high-tax period
} 
Step (iii): Differences in book-tax conformity. Prior theoretical models on intertemporal shifting of taxable income generally assume strict book-tax conformity (e.g., Randolph et al. 2005). Further, prior studies argue that the accrual of expenses and deferral of income for tax purposes is a sufficient but not necessary condition of recognition for financial statement purposes (Guenther et al. 1997). However, there are several examples of differences in how income and expenses are recognized for GAAP versus tax purposes. For example, due to the modified cash basis of accounting employed by Internal Revenue Code, in certain circumstances, firms are allowed to delay the recognition of book revenue for tax purposes until the revenue is collected in cash or deduct prepaid expenses that are not recognized as book expenses. ${ }^{8}$ Importantly, many of these items create deferred tax adjustments that can offset increases in GAAP net income due to AEM. We assume the AEM undertaken in our model does not result in deferred tax adjustments. ${ }^{9}$ Moreover, even in the presence of deferred tax adjustments, AEM will result in increases in pre-tax income and in many cases sales or gross margins, which are important earnings benchmarks.

Consistent with these conjectures, Zang (2012) argues that REM has higher book-tax conformity than AEM because REM has a direct cash flow effect in the current period while AEM does not. She provides empirical evidence that the marginal tax rate is a larger cost factor of REM relative to AEM. Thus, when the marginal tax rate is high, a firm prefers to use AEM instead of REM to meet/beat earnings targets due to the lower book-tax conformity of AEM. ${ }^{10}$ As the specific levels of book-tax conformity of REM and AEM are unknown, we model the relative difference in the book-tax conformity between these two earnings manipulation

(e.g., overproduction to compensate for underproduction in the previous period to restock inventories). Thus, we examine both the reversal of REM and AEM in our empirical analyses.

${ }^{8}$ See IRS (2019) for a discussion of the recurring item exceptions for the deferral of revenue and deduction of prepaid expenses. Common prepaid expenses include compensation, benefits, taxes, and other services.

${ }_{9}^{9}$ We explicitly test this conjecture when we examine non-current accruals, which are less likely to generate deferred tax adjustments (Guenther et al. 1997).

${ }^{10}$ For example, when a firm cuts discretionary expenses, this also increases taxable income and incurs higher tax expenses. In contrast, when a firm delays goodwill impairments in the books, this generally does not increase taxable income due to the non-deductibility of goodwill impairments (King, Lynch, Stromberg, and Utke 2020). 
methods. Thus, we define $\beta \in] 0,1[$ as a measure for the partial book-tax conformity of AEM relative to REM. ${ }^{11}$

Step (iv): Constraints from earnings targets. Firms face financial reporting pressure from capital market participants to meet/beat earnings targets (Graham, Harvey, and Rajgopal 2005). Management compensation contracts are also associated with incentives to meet earnings thresholds (Cheng and Warfield 2005). The prior literature demonstrates that firms use both REM and AEM to meet/beat such earnings targets (Roychowdhury 2006; Zang 2012). Consequently, a firm's flexibility to use REM and AEM to reduce taxes is often constrained by the incentives to meet/beat earnings targets (Matsunaga et al. 1992). In our model, this issue is particularly important for the high-tax period $(t=1)$ because the firm is incentivized to manipulate income downwards to save taxes. Thus, we model the constraint to meet/beat the earnings benchmark in the earlier period as follows:

$$
i_{1}^{\text {pre }}+m_{r}+m_{a} \geq z
$$

$i_{1}^{\text {pre }}$ is the pre-tax income before REM and AEM in $t=1 . z$ is a book pre-tax earnings target (e.g., the zero earnings target in financial reporting). Importantly, book-tax conformity is not relevant for this condition because the pressure from capital market participants refers to book earnings. Consistent with incentives to slightly meet/beat earnings targets (Burgstahler and Dichev 1997), this term transfers to an equation $\left(i_{1}^{\text {pre }}+m_{r}+m_{a}=z\right) .{ }^{\mathbf{1 2}}$

${ }^{11}$ To provide descriptive evidence for a higher level of book-tax conformity of REM relative to AEM, we study the association of pre-tax income in the tax accounts to lagged total assets with AEM and REM, respectively. When the assumption that REM has a higher level of book-tax conformity than AEM is correct, REM should more strongly map into taxable income $\left(T I_{i t}\right)$ than AEM. Therefore, we separately estimate the following regressions on the firm-level over the 2000 to 2019 interval with annual data. Then, we compare their mean explanatory power (adj. $R^{2}$ ) of REM and AEM.

$$
T I_{i t}=\beta_{0}+\beta_{1} R E M_{i t}+u_{i t} \text { and } T I_{i t}=\beta_{0}+\beta_{1} A E M_{i t}+u_{i t}
$$

$R E M_{i t}$ and $A E M_{i t}$ as defined in Appendix B. We define $T I_{i t}$ in line with the book-tax difference literature (Kim, $\mathrm{Li}$, and Zhang 2011). Appendix C provides technical details. Consistent with our assumption, we find that REM (mean adj. $\left.\mathrm{R}^{2}=12.0 \%\right)$ maps stronger into taxable income than AEM (mean adj. $\left.\mathrm{R}^{2}=7.5 \%\right)(p<1 \%)$ which descriptively substantiates our assumption of higher book-tax conformity of REM relative to AEM.

${ }^{12}$ The firm might also seek to meet/beat an earnings target in the later period. We assume that reaching the earlier earnings target is more important for the determination of $m_{r}$ and $m_{a}$ in and/or at the end of the first period because 
Step (v): Profit maximization. Under the assumption that discounting effects are negligible in our two period setting, we postulate that a firm seeks to maximize the total (aftertax) profit $\left(\pi=i_{1}+i_{2}\right)$ over the two periods:

$$
\begin{aligned}
& \max _{m_{r}, m_{a}} \pi \\
& =\max _{m_{r}, m_{a}}(\underbrace{\left[i_{1}^{\text {pre }}+m_{r}+\beta m_{a}\right] \times\left(1-\tau_{1}\right)}_{i_{1}}+\underbrace{\left[i_{2}^{\text {pre }}-m_{r}-c_{r}\left(m_{r}\right)-\beta m_{a}\right] \times\left(1-\tau_{2}\right)}_{i_{2}})
\end{aligned}
$$

$i_{t}^{\text {pre }}$ is the pre-tax income before REM and AEM in period $t$. To solve the maximization problem, we note that the constraint given in Step (iv) has to be fulfilled in the optimum. ${ }^{\mathbf{1 3}}$ Then, we can rearrange the maximization problem as follows:

$$
\begin{gathered}
\max _{m_{r}} \pi=\max _{m_{r}}\left(\left[i_{1}^{\mathrm{pre}}+m_{r}+\beta\left(z-i_{1}^{\mathrm{pre}}-m_{r}\right)\right] \times\left(1-\tau_{1}\right)\right. \\
\left.+\left[i_{2}^{\text {pre }}-m_{r}-c_{r}\left(m_{r}\right)-\beta\left(z-i_{1}^{\text {pre }}-m_{r}\right)\right] \times\left(1-\tau_{2}\right)\right)
\end{gathered}
$$

The first derivative of this formula leads to the following solution: ${ }^{14}$

$$
\underbrace{(1-\beta)}_{>0} \times \underbrace{\left(\tau_{2}-\tau_{1}\right)}_{<0}=c^{\prime}{ }_{r}\left(m_{r}\right) \times \underbrace{\left(1-\tau_{2}\right)}_{>0}
$$

Irrespective of the specific magnitude of each parameter, this term indicates that $c_{r}^{\prime}\left(m_{r}^{*}\right)<0$ is necessary to solve the condition. Taking the properties of the cost function assumption given in Step (ii), this implies $m_{r}^{*}<0$. In other words, independent from the magnitude of AEM and the level of book-tax conformity $(\beta)$, firms always use REM to shift

there is already high certainty about the non-manipulated pre-tax income in the first period $\left(i_{1}^{\text {pre }}\right)$ relative to the non-manipulated income in the second period $\left(i_{2}^{\text {pre }}\right)$.

${ }^{13}$ Please consider the unconstrained maximization condition. $\partial \pi / \partial m_{a}=\beta \times\left(\tau_{2}-\tau_{1}\right)<0$ implies that the firm can always increase profit by choosing a lower level of $m_{a}$ as long as the condition is not binding.

${ }^{14}$ The solution $\left(m_{r}^{*}\right)$ is a maximum because the second order condition is negative $\left(\partial^{2} \pi / \partial m_{r}^{2}=-c^{\prime \prime}{ }_{r}\left(m_{r}^{*}\right)<0\right)$. From this equation, the following further insights can be inferred. First, we observe $\partial c^{\prime}{ }_{r}\left(m_{r}\right) / \partial \beta>0$. Given that the cost function of REM is convex, this implies that the optimal level of REM $\left(m_{r}^{*}\right)$ increases with the book-tax conformity of $\operatorname{AEM}(\beta)$, thus the optimal level of AEM $\left(m_{a}^{*}\right)$ decreases with its book-tax conformity. Intuitively, if $\beta$ increases, the firm relies less on negative REM and substitutes by shifting through lower levels of costless AEM instead. Second, we note $\partial c^{\prime}{ }_{r}\left(m_{r}\right) / \partial \tau_{1}=-(1-\beta) /\left(1-\tau_{2}\right)<0$ and $\partial c^{\prime}{ }_{r}\left(m_{r}\right) / \partial \tau_{2}=(1-\beta) \times(1-$ $\left.\tau_{1}\right) /\left(1-\tau_{2}\right)^{2}>0$. This observation implies that the magnitude of negative REM increases with the tax rate of the high-tax period $\left(\tau_{1}\right)$ and decreases with the tax rate of the low-tax period $\left(\tau_{2}\right)$. Therefore, income shifting increases if the tax-related incentives increase. 
taxable income from the high-tax period to the low-tax period. Taking the conclusions from our theoretical model, we state the following first hypothesis:

H1: Firms use REM to shift taxable income from high-tax periods to low-tax periods.

Turning to AEM, we apply the condition given in Step (iv), leading to the following optimal level of $\operatorname{AEM}\left(m_{a}^{*}\right)$.

$$
m_{a}^{*}=\left(z-i_{1}^{\text {pre }}\right)-m_{r}^{*}
$$

This formula implies that the optimal level of AEM depends on the gap between the given earnings target and the pre-tax income before REM and AEM $\left(z-i_{1}^{\text {pre }}\right)$ along with the computed optimal level of REM $\left(m_{r}^{*}\right)$. We argue that both internal (e.g., earnings-related compensation goals) and external earnings targets (e.g., analyst forecasts) are set in a way that managers can realistically meet them (Matsumoto 2002; Richardson, Teoh, and Wysocki 2004; Cotter, Tuna, and Wysocki 2006). ${ }^{\mathbf{1 5}}$ Consequently, we assume that the difference between the earnings target and the non-manipulated actual earnings is generally small. Given that the optimal level of REM in the high-tax period is likely to be negative $\left(m_{r}^{*}<0\right)(\mathrm{H} 1)$, we predict that the optimal level of AEM $\left(m_{a}^{*}\right)$ is positive. ${ }^{16}$ This prediction implies that a firm uses income-increasing AEM to meet/beat the earnings target (Zang 2012). We formalize this prediction as follows:

H2: Firms use AEM to shift book income from low-tax periods to high-tax periods to offset decreases in book income due to REM.

\footnotetext{
${ }^{15}$ Consistent with this conjecture, $88.1 \%$ of all quarterly earnings in our sample, defined as earnings-per-share to the stock price at the beginning of the quarter, are in the $1 \%$-interval around the last median consensus earnings forecast issued prior to the end of the fiscal quarter in our sample.

${ }^{16}$ We note that it is also possible that the difference between the earnings target and the non-manipulated pre-tax income $\left(z-i_{1}^{\text {pre }}\right)$ is lower than the optimal level of REM $\left(m_{r}^{*}\right)$, leading to an optimum with income-decreasing AEM in the high-tax period $\left(m_{a}^{*}<0\right)$. This would imply that a firm engages in AEM to shift pre-tax income from the high-tax to the low-tax period to realize additional tax savings biasing against our predicted effect.
} 


\section{DATA AND SAMPLE}

To test our hypotheses, we use quarterly data collected from the June 30, 2020 version of the quarterly file of the COMPUSTAT database, financial analyst data from the IBES database, and economic variables from the WORLDBANK database. Table 1 contains details of our sample selection process. Our starting sample contains all listed US firms included in the COMPUSTAT database in the January 2010 to December 2019 interval. We begin in January 2010 to avoid confounding effects of the 2008/2009 international financial crisis and end our sample in 2019 as 2020 data might be affected by the COVID-19 virus pandemic. ${ }^{17}$

Our initial sample consists of 229,929 firm-quarter observations from 9,358 unique US firms with quarterly sales available in the COMPUSTAT database. We eliminate observations that refer to fiscal years with a length unequal to twelve months and fiscal quarters with a length unequal to three months. We also drop all firms from regulated industries and firms from the financial and insurance industry. To promote meaningful longitudinal comparisons of firms' REM and AEM, we drop firms with total assets of less than $\$ 1$ million, firms with missing data, and firms with less than 10 observations over our investigation period. The final sample for our analyses consists of 21,221 firm-quarter observations from 851 firms.

\section{Identification Strategy}

\section{RESEARCH DESIGN}

Figure 1 summarizes the legislative process leading to the enactment of the TCJA. Approximately one year after the election of Donald J. Trump, the TCJA bill was formally introduced to the House (November 2017). After its approval by the House and the Senate, the US President signed the bill into law in December 2017. The reduced corporate tax rate became effective from January 2018 onwards. Firms with fiscal year ends different from December face a blended tax rate for the fiscal year ending in 2018. The blended tax rate is defined as the

\footnotetext{
${ }^{17}$ A control period which contains observations from the interval prior to and after the treatment intervals lowers the likelihood that our analyses pick up overall time trends rather than the hypothesized effects. Nevertheless, we note that the tenor of our results remains unchanged when we exclude the fiscal year 2019.
} 
weighted average of the $35 \%$ tax rate prior to the enactment of the TCJA and the new $21 \%$ tax rate, weighted by the days of the fiscal year in 2017 and 2018, respectively. Table 2 reports the corporate tax rates for firms with different fiscal year ends. Most important for our identification strategy, this timeline suggests a series of time intervals that are characterized by specific incentives for intertemporal shifting of taxable income (Scholes et al. 1992).

\section{Expect Interval}

The outcome of the 2016 election was unexpected to many (Wagner et al. 2018a). Therefore, it is unlikely that firms anticipated significant tax reform before the election in late 2016. As The Republican Party controlled both Presidency and Congress after the election, it became clear that policy changes, including tax reform, were likely to occur because tax breaks were a key pledge of the Republicans' $2016^{\text {th }}$ election campaigns (Wagner et al. 2018b). Consequently, we argue that managers anticipated future tax cuts in the period beginning in 2017 following the 2016 election. Thus, our first treatment period, denoted as the 'expect interval' $\left(E X P_{t}=1\right)$, is defined as the four fiscal quarters before the new tax rate of $21 \%$ applies. ${ }^{18}$ When the fiscal year is identical to the calendar year, the 'expect interval' is the calendar year 2017. When the fiscal year differs from the calendar year, firms face a blended tax rate weighted by the number of days in 2017 and 2018. For example, a firm with a fiscal year end in March 2018 has a blended tax rate of 31.5\% for the fiscal year 2017/2018 (Table 2). Analogously, we define the 'expect interval' of these firms as the four fiscal quarters before the new tax rate of $21 \%$ applies which is the interval from April 2017 to March 2018. We also leverage differences in the tax rate incentives to shift income over time in our empirical design by defining the 'expect interval' with a continuous measure of the tax rate savings differential. ${ }^{19}$

\footnotetext{
${ }^{18}$ We study whether our assumptions about the expectation formation process prior to the enactment of the TCJA affects our findings. We find that eliminating the period between the 2016 election and the 'expect interval' does not change the tenor of our results. Further, we show that our results are robust to expanding the 'expect interval' to the period between the $2016^{\text {th }}$ election and the effectiveness of the TCJA.

${ }^{19}$ Besides the reduction of the federal tax rate, the TCJA also affects several international provisions, including a shift to a quasi-territorial system with deems repatriation tax, global intangible low-tax income taxes (GILTI), and
} 


\section{Effective Interval}

The second treatment period, denoted as 'effective interval' $\left(E F F_{t}=1\right)$, is defined as the earliest four quarters for which the $21 \%$ tax rate applies. Once again, this interval depends on the fiscal year end of the firm. For a firm with a fiscal year end in December, the 'effective interval' is defined as the four quarters ending in calendar year 2018 while for a firm with a fiscal year end in March 2018, the 'effective interval' is defined as the four quarters ending between April 2018 and March 2019.

\section{Regression Models}

To provide empirical evidence on income shifting via REM and AEM around the enactment of the TCJA, we separately estimate the following OLS regressions for our panel dataset. Test statistics are calculated based on firm-level clustered standard errors: ${ }^{\mathbf{2 0}}$

$$
\begin{aligned}
& R E M_{i t}=\beta_{0}+\beta_{1} E X P_{t}+\beta_{2} E F F_{t}+\beta_{3} T R E N D_{t} \\
& \quad+\text { controls }+\sum \beta F_{i}+\sum \beta C Q_{t}+\sum \beta F Q_{t}+u_{i t} \\
& A E M_{i t}=\beta_{0}+\beta_{1} E X P_{t}+\beta_{2} E F F_{t}+\beta_{3} T R E N D_{t} \\
& \quad+\text { controls }+\sum \beta F_{i}+\sum \beta C Q_{t}+\sum \beta F Q_{t}+u_{i t}
\end{aligned}
$$

$R E M_{i t}$ is the REM of firm $i$ in the fiscal quarter $t$, defined as abnormal production costs, minus abnormal R\&D expenses, minus abnormal SG\&A expenses. $A E M_{i t}$ is the AEM of firm $i$ in the fiscal quarter $t$, defined as discretionary accruals estimated in a Jones (1991)-type model (Zang 2012). Appendix B provides detailed definitions of our earnings management proxies.

In addition to economy-wide controls, we consider the overall time trend in REM and AEM and include a linear trend control $\left(\operatorname{TREND}_{t}\right)($ Cohen et al. 2008). We also include several controls, ${ }^{21}$ firm fixed effects $\left(F_{i}\right)$, indicators for the four calendar quarters $\left(C Q_{t}\right)$, and for the

\footnotetext{
base erosion and anti-abuse taxes (BEAT) (Donohoe et al. 2019). Section VII contains additional analyses which suggest that our findings are not driven by TCJA-related incentives of multinationals.

${ }^{20}$ We note that robust standard errors lead to unchanged inference.

${ }^{21}$ In our quarterly setting, it is reasonable to assume that REM and AEM are simultaneously determined based on their relative costs and effects on book and tax income. Although we apply the cost-framework proposed by Zang (2012), we note our results could differ for three reasons. First, we do not focus on a sample of firms with strong
} 
four fiscal quarters $\left(F Q_{t}\right)$. Firm fixed effects control for a large set of time-invariant firm characteristics potentially related to the costs and benefits of income shifting through REM and AEM. Referring to H1 (Equation 1), ceteris paribus, we predict that $\beta_{1}<0$ and $\beta_{2}>0$ consistent with the use of REM to shift taxable income from the high-tax period $\left(E X P_{t}=1\right)$ to the low-tax period $\left(E F F_{t}=1\right)$. Referring to $\mathrm{H} 2$ (Equation 2), ceteris paribus, we hypothesize that $\beta_{1}>0$ and $\beta_{2}<0$ consistent with the use of AEM to increase book income in the hightax period to offset the decrease due to REM.

\section{Control Variables}

We include control variables for the relative costs associated with REM and AEM, fundamental firm characteristics, and the economic environment (Zang 2012; Ernstberger et al. 2017). First, to proxy for the (relative) costs associated with REM, we include the sales market share of a firm $\left(S H A R E_{i t-1}\right)$ because a firm's competitive advantages associated with its market leadership may influence the flexibility to conduct REM. We add Altman's (1968) z-score $\left(Z S C O R E_{i t-1}\right)$ as a proxy for the overall financial health because financially distressed firms are less able to use REM (Zang 2012). We also control for institutional ownership $\left(I N S T_{i t-1}\right)$ because close monitoring by sophisticated investors reduces the flexibility to use REM (Bushee 1998; Roychowdhury 2006).

Second, to proxy for the (relative) costs associated with AEM, we include a big four audit firm indicator $\left(\right.$ BIGFOUR $\left._{i t}\right)$ (Becker et al. 1998) and the experience of an auditor with a client (TENURE $\left.E_{i t}\right)$ as both could constrain AEM (Myers et al. 2003). Following Barton and Simko (2002), we control for a firm's AEM balance sheet constraints. $\left(N O A_{i t-1}\right)$. We include a proxy for the length of a firm's operating cycle $\left(C Y C L E_{i t-1}\right)$ because a longer operating cycle increases flexibility to engage in AEM and makes REM less attractive (Cohen et al. 2008).

income-increasing earnings management incentives, second, we do not use the same fixed effects strategy, and third we do not make strong assumptions about the sequence of REM and AEM. 
We also control for a firm's operating profitability $\left(R O A_{i t}\right)$, industry-adjusted size $\left(\operatorname{ASSETS}_{i t}\right)$, market valuation $\left(M T B_{i t}\right)$, and pre-managed operating profitability which is the “starting level” of any earnings management $\left(E A R N_{i t}\right)$ (Beatty et al. 1995; Zang 2012). Further, in addition to our linear trend control, we include three variables that control for the market and economic environment (Cohen et al. 2008; Ernstberger et al. 2017). Specifically, we include the real growth rate of the US gross domestic product $\left(E C O N_{t}^{\text {growth }}\right)$, the return of the S\&P 500 index $\left(E C O N_{t}^{\text {ret }}\right)$, and overall stock market liquidity $\left(E C O N_{t}^{\mathrm{vol}}\right)$. Appendix C provides detailed variable definitions.

\section{RESULTS}

\section{Descriptive Statistics and Correlations}

Panel A (Panel B) of Table 3 shows descriptive statistics for our earnings management measures (control variables). Overall, the means and medians are consistent with the prior literature (Cohen et al. 2008) which suggests that we have constructed a representative sample of large publically traded firms. Table 4 presents correlations for our REM and AEM measures and the control variables. Consistent with prior literature, we find that $R E M_{i t}$ and $A E M_{i t}$ are positively correlated with each other $(p<1 \%$ ) (Roychowdhury 2006; Cohen and Zarowin 2010; Zang 2012). Other correlations indicate that multi-collinearity is not a concern.

\section{Univariate Results}

Panel A (Panel B) of Table 5 provides univariate tests of REM (AEM) and their components for the two treatment periods vis-à-vis the control period. Consistent with H1, we find that firms exhibit mean income-decreasing REM in the period prior to the TCJA (i.e., expect interval), relative to the control period $(p<1 \%)$. We also document that firms conduct mean and median income-increasing AEM in the period prior to the TCJA, relative to the control period $(p<1 \%)$ presumably to offset the income shifting through REM. Furthermore, we observe income-decreasing AEM in the period following the TCJA (i.e., effective interval). 
Figure 2 shows the calendar year (Panel A) and calendar quarter (Panel B) means of $R E M_{i t}^{\text {adj }}$ and $A E M_{i t}^{\text {adj }}$ around the effectiveness of the TCJA. REM $M_{i t}^{\text {adj }}\left(A E M_{i t}^{\text {adj }}\right)$ is defined as $R E M_{i t}$ $\left(A E M_{i t}\right)$ adjusted for a linear trend $\left(T R E N D_{t}\right)$ and fiscal and calendar quarter effects. The figure patters are consistent with the view that firms use REM to lower taxable income in the high-tax period and use AEM to offset the decrease in book income with a subsequent reversal of AEM in the four-quarter period following the TCJA. These effects do not appear in other years or calendar-quarters providing univariate evidence consistent with our hypotheses.

\section{Main Regression Results}

Table 6 displays the main regression results. In Column 1, where REM is the dependent variable (equation 1), we find a significantly negative coefficient on $E X P_{t}$ consistent with firms using REM to reduce taxable income in the period prior to the enactment of the TCJA $\left(\beta_{1}<0\right.$, $p<1 \%$ ). We observe a significantly positive coefficient on $E F F_{t}$ consistent with incomeincreasing REM in the subsequent period $\left(\beta_{2}>0, p<1 \%\right)$. An F-test suggests that the unsigned magnitudes of these coefficients do not significantly differ $(p>10 \%)$ consistent with a full reversal of REM in the year following the TCJA. Combined, these results suggest that firms use REM to shift income from the high-tax to the low-tax period.

To assess the economic significance of our results, we define yearly REM as four times the coefficients of the regression analyses with quarterly data presented in the table. Ceteris paribus, we document mean income-decreasing REM of $0.8 \% \times 4=3.4 \%$ relative to lagged total assets in the 'expect interval' and a mean reversal (income-increasing REM) of $0.5 \% \times$ $4=2.0 \%$ relative to lagged total assets in the 'effective interval' period. We also compute the overall tax savings of this strategy. Under the assumption of full book-tax conformity of REM and zero book-tax conformity of AEM, we estimate a reduction of tax payments through REM 
of $\$ 37.5$ million per firm and aggregated tax savings of roughly $\$ 31.9$ billion for the 851 firms of our sample. ${ }^{22}$

In Column 2, where AEM is the dependent variable, we find a positive and statistically significant coefficient on $E X P_{t}$ consistent with firms using AEM to increase book income in the period prior to the TCJA enactment to offset the observed decrease in book income due to REM $\left(\beta_{1}>0, p<1 \%\right)$. We also observe a significantly negative coefficient on $E F F_{t}$ consistent with the AEM reversing in the subsequent period $\left(\beta_{2}<0, p<1 \%\right)$. Ceteris paribus, we find mean income-increasing AEM of $0.7 \% \times 4=2.7 \%$ relative to lagged total assets in the earlier period and mean income-decreasing AEM of $0.5 \% \times 4=1.9 \%$ relative to lagged total assets in the latter period. An F-test indicates that the unsigned magnitudes of these coefficients do not significantly differ $(p>10 \%)$ consistent with a full reversal of AEM in the year following the TCJA. Combined, consistent with H2, these results suggests firms use AEM to increase book income in the period prior to the TCJA to offset the decrease due to REM.

\section{Magnitude of Income Shifting Incentives}

We also examine whether the income shifting around the TCJA differs based on the magnitude of the potential tax savings incentives. Due to the blended tax rate approach, the tax saving incentives depend on the date of the firm's fiscal year end (Scholes et al. 1992). In a first set of analyses, for the four fiscal quarters preceding the $21 \%$ tax rate ('expect interval'), we replace our binary indicator $\left(E X P_{t}\right)$ with a measure for the percentage magnitude of the potential tax saving benefits, i.e., the tax rate of the current fiscal year minus the tax rate of the next fiscal year $\left(E X P_{t}^{\text {incentive }}\right.$; Table 2). Consistently, our findings reported in Column 3 and 4

\footnotetext{
${ }^{22}$ In the high-tax period the change in firm tax payments is equal to $3.4 \% \times 35 \%=1.2 \%$ relative to lagged total assets. Similarly, we estimate a reversal-related increase of tax burdens in the low-tax period of $2.0 \% \times 21 \%=$ $0.4 \%$ relative to lagged total assets. To estimate the tax savings, we note that the average firm of our sample realizes tax savings of $1.2 \%-0.4 \%=0.8 \%$ relative to lagged total assets. The mean lagged total assets of the 851 firms of our sample is $\$ 5.0$ billion. Thus, the average total tax savings per firm is calculated to be $0.8 \% \times$ $\$ 5.0$ billion $=\$ 37.5$ million. Aggregated across our sample, this equals $\$ 37.5$ million $\times 851=\$ 31.9$ billion .
} 
of Table 6 suggest that firms decrease (increase) income with REM (AEM) in the four quarters prior to the effectiveness of the TCJA.

Second, we recognize that the tax saving incentives are highest for firms with a fiscal year equal to the calendar year (Table 2). Therefore, for the analyses presented in Column 5 and 6, we restrict our sample to these firms. We find that the magnitudes of the income shifting coefficients are significantly larger than in the baseline specification in Column 1 and $2 .^{23}$ Overall, our results are consistent with tax incentives being the primary driver of our observed pattern of earnings management results.

\section{ADDITIONAL ANALYSES}

To provide further evidence that the tax rate change is driving the observed patterns in firm behavior, we examine both the timing of the response and the specific earnings management techniques. Further, we demonstrate that pressure to meet/beat earnings targets is a key determinant of our AEM results. For all additional analyses, we use calendar year end firms as they have the strongest earnings management incentives around the TCJA. ${ }^{24}$

\section{Timing of Income Shifting}

The passage of the tax reform did not occur until the end of 2017 and there was significant doubt about its specific details throughout the process (Gaertner et al. 2020). Thus, it is possible that firms' earnings management responses occurred primarily in the quarters immediately prior to and following the effectiveness of the new tax rate. Therefore, we redefine the intervals around the enactment of the TCJA. First, we define the 'expect interval' as the two fiscal quarters before the TCJA $\left(E X P_{t}\right)$ and the subsequent two fiscal quarters as the 'effective

\footnotetext{
${ }^{23}$ To test whether calendar year end firms differ from other firms, we include an indicator that takes a value of one if the firm is a calendar year end firm and its interaction with the indicator for the 'expect interval' into our regression model. We note that the coefficient on this interaction term is significant $(p<1 \%)$ while the first-order effect becomes insignificant $(p>10 \%)$. We take this pattern as evidence that calendar year firms drive our primary results. This is consistent with our assumption that tax incentives affect income shifting around the TCJA. ${ }^{24}$ Untabulated results suggest that our findings remain unchanged when we run these analyses for the full sample.
} 
interval' $\left(E F F_{t}\right)$. The results are presented in Column 1 and 2 of Table 7. Second, we limit our treatment periods to the last quarter before the TCJA $\left(E X P_{t}\right)$ and the first quarter after the TCJA $\left(E F F_{t}\right)$. The findings are displayed in Column 3 and 4.

The results of both specifications are consistent with our major findings. We find the effect magnitudes in the 'expect interval' are stronger when we use tighter treatment intervals around the TCJA effectiveness. We find that REM and AEM conducted in the second half of the high-tax fiscal year before the TCJA do not fully reverse in the first half of the subsequent low-tax fiscal year (Column 1 and 2 of Table 7). However, we do find evidence that the REM and AEM conducted in the last quarter of 2017 fully reversed in the first quarter of 2018 (Column 3 and 4 of Table 7). Overall, these patterns suggest that an important portion of REM and AEM occur in the quarters immediately prior to and after TCJA enactment.

\section{Accrual-Based Earnings Management and Financial Reporting Pressure}

A key assumption of our theoretical model is that firms experience pressure to meet/beat earnings targets. In this analysis, we explicitly study whether income-increasing AEM in the high-tax period is stronger for firms that face financial reporting pressure to meet/beat earnings targets. We argue that "habitual earnings targets beaters", i.e., firms that frequently meet/beat earnings targets, are more likely to experience pressure to meet/beat such thresholds also in the

current fiscal quarter (Bartov, Givoly, and Hayn 2002; Zang 2012). We code the indicator $H A B I T U A L_{i t}$ as one if the firm is in the upper quartile of the number of suspect fiscal quarters over the prior three fiscal years (Lynch, Romney, Stromberg, and Wangerin, 2019). We include $H A B I T U A L_{i t}$ and its interactions with our treatment indicators in Equation (2):

$$
\begin{aligned}
& A E M_{i t}=\beta_{0}+\beta_{1} H_{A B I T U A L_{i t}}+\beta_{2} E X P_{t}+\beta_{3}\left(E X P_{t} \times H A B I T U A L_{i t}\right)+\beta_{4} E F F_{t} \\
& +\beta_{5}\left(E F F_{t} \times H_{\text {HBITUAL }}\right)+\text { controls }+\sum \beta F_{i}+\sum \beta C Q_{t}+\sum \beta F Q_{t}+u_{i t}
\end{aligned}
$$

The results of this model are presented in Table 8 . We find that that the coefficient on $E X P_{i t}$ is $1.1 \%(p<1 \%)$ and that the coefficient on the interaction $\left(E X P_{t} \times H A B I T U A L_{i t}\right)$ is 
$2.4 \%(p=2 \%)$. This pattern suggests that AEM in the interval prior to the TCJA is more than two-times higher for firms that face high financial reporting pressure. These findings support our primary analyses and illustrate that firms facing higher financial reporting pressure use more AEM to offset earnings decreases due to REM.

\section{Current and Non-Current Accruals}

There is a different degree of book-tax conformity for certain types of accruals. Noncurrent accruals (e.g., impairment of assets with zero tax basis) generally exhibit lower booktax conformity than current accruals (e.g., accrual of revenue; Guenther 1994). Therefore, if book-tax conformity is the primary factor in choosing the method of earnings management, we predict that firms use the non-current accruals portion of AEM to offset reductions in book income through REM. In contrast, we argue that current accruals are unlikely to offset tax saving-motivated REM due to the relatively higher level of book-tax conformity (i.e., an income-increasing current accrual will also increase taxable income).

Table 9 displays the results after bifurcating AEM into abnormal current and abnormal non-current accruals. Consistent with our predictions, we find no evidence of the use of abnormal current accruals $\left(A C A_{i t}\right)$ to shift book income around the TCJA (Guenther 1994). In contrast, we find positive (negative) coefficients on $E X P_{t}\left(E F F_{t}\right)$ using abnormal non-current accruals $\left(A N C A_{i t}\right)$ as the dependent variable $(p<1 \%)$. Taken together, these results suggest that firms primarily use non-current accruals, which have lower book-tax conformity, to increase book income in the period prior to the TCJA, presumably to offset the decreases in book income due to REM.

\section{Real Earnings Management Techniques}

To better understand the use of different REM techniques, we decompose REM into its components of overproduction $\left(A P R O D_{i t}\right)$, abnormal R\&D expenses $\left(A R D_{i t}\right)$, and abnormal 
SG\&A expenses $\left(A S G A_{i t}\right){ }^{25}$ Our findings presented in Table 10 suggest that firms use all three REM techniques to lower tax burdens in the high-tax period prior to the TCJA. Our results also indicate that firms quickly restock their inventories in the 'effective interval' after the observed underproduction in the 'expect interval'. We also document a reversal of R\&D activities in the 'effective interval' but do not find a reversal of SG\&A activities in the period after the TCJA.

\section{Robustness Tests}

We perform the following robustness tests to improve the validity of our inferences. First, we create pseudo-event dates that are assigned around the TCJA enactment date as a falsification test. Then, we re-run our REM and AEM regressions with these pseudo-event dates. Supporting the internal validity of our study, we find that the documented effects for REM and AEM around the enactment of the TCJA steadily weaken when we counterfactually move away from the true effectiveness date of the TCJA (Christensen, Hail, and Leuz 2016). ${ }^{\mathbf{2 6}}$ These results (untabulated) suggest that the earnings management behavior of firms changed around the effective date of the TCJA and not around other financial reporting dates.

Second, prior studies suggest that classic two-step approaches to approximate abnormal earnings management, i.e., estimation of REM and AEM measures in a first step (Appendix B) and then analyze the calculated residuals in a second step, might lead to biased evidence (Chen, Hribar, and Melessa 2018). To mitigate such concerns, we apply the approach proposed by Chen et al. (2018) and replace the explanatory variables of the second-step regressions (Equation 1 and 2) with the residuals from regressions of these second-step explanatory variables on the respective first-stage explanatory variables (Appendix B). The (untabulated)

\footnotetext{
${ }^{25}$ We acknowledge that R\&D expenditures qualify for a tax credit in the US setting, thus potentially negating the tax rate differential incentives. However, it is important to note that many firms do not qualify for the R\&D tax credit and if they do not all R\&D expenditures qualify for the tax credit (BDO 2018).

${ }^{26}$ More specifically, for REM (AEM), the coefficient on the indicator for the 'expect interval' $(p<1 \%)$ reduces to $-0.5 \%(0.5 \%),-0.7 \%(0.7 \%),-0.7 \%(0.6 \%)$, and $-0.5 \%(0.4 \%)$ when we counterfactually shift the end date of the 'expect interval' two quarters backwards, one quarter backwards, one quarter ahead, and two quarters ahead, respectively.
} 
results for our hypotheses are overall consistent with our two-step specification. More specifically, the coefficients on the 'expect interval' indicator are significant as predicted $(p<$ 1\%) while we find significant reversals only for $A P R O D_{i t}$ and $A E M_{i t}$.

Third, we consider the tax paying status of the firm. Ignoring net operating losses, we argue that firms with positive current tax expense have stronger incentives to engage in earnings management around the tax rate change. Therefore, we define an indicator that takes a value of one if a firm had positive current tax expense (\#txc) in 2017 and include the interaction of this indicator with our treatment interval indicators. The interaction with the 'expect interval' indicator remains insignificant in all specifications (untabulated, $p>0.1$ ).

We believe this lack of reduced earnings management for firms with negative tax expense could be explained by net operating loss carry back incentives. More specifically, the TCJA changed the treatment of net operating losses. Prior to the TCJA, losses could be carried back two years and forward 20 years. After the TCJA, losses are carried forward indefinitely and are subject to limitation. Thus, 2017 generally represents a firm's "last chance" to create a loss and carry it back to 2016. Therefore, we examine firms that receive a tax refund in 2017 due to a loss carry back to 2016. Specifically, we set an indicator that takes a value of one if a firm has positive current tax expense (\#txc) in 2016 and negative current tax expense in 2017. In the REM analyses, the interaction effect of this indicator with the 'expect interval' is negative and statistically significant (untabulated, $p=6 \%$ ). We take this finding as evidence that firms that carried back a loss from 2017 to 2016 conducted more negative REM in 2017.

Fourth, we attempt to rule out the effects of other TCJA changes that could affect the earnings management of firms. The TCJA fundamentally changed the international taxation of US firms, e.g., move to a territorial system with a deemed repatriation tax, global intangible low-taxed income tax (GILTI), foreign derived intangible income (FDII), and BEAT (Donohoe, McGill, and Outslay 2019). These international provisions likely affect firm behavior after taking effect in 2018 and therefore, are unlikely to affect our estimates during the 'expect 
interval'. However, to account for the possibility that international provisions affect our results, we split the sample into domestic and international firms, defined as firms that report non-zero foreign pre-tax income (\#pifo) during our sample period. We find that both domestic and international firms engage in REM and AEM around the TCJA as documented in our primary analyses (untabulated). More specifically, in the REM and AEM regressions, we find significant coefficients on the 'expect interval' indicator $(p<1 \%)$ and significant coefficients on the 'effective interval' indicator ( $p<10 \%)$, with the exception of REM for domestic firms.

Fifth, the reduction of the corporate tax rate required firms to revalue their deferred tax balances in 2017. To ensure that our observed pattern of AEM is not affected by the reevaluation of deferred taxes, we split our sample at the median of net deferred taxes (\#txndb) to lagged total assets in the year before the reevaluation (i.e., 2016). We find that our main results are unchanged for the firms across these two groups (untabulated). More specifically, in the REM and AEM regressions, we find significant coefficients on the 'expect interval' indicator $(p<1 \%)$ and on the 'effective interval' indicator $(p<5 \%)$.

\section{CONCLUSION}

This paper provides evidence on firms' REM and AEM around the corporate tax rate decrease of the TCJA. We predict and find that firms engage in REM to shift income from the high-tax period prior to the TCJA to the low-tax period after the TCJA to reduce tax burdens. Due to a lower book-tax conformity of AEM relative to REM, we also document that firms use AEM to offset the decrease in book income from REM, presumably due to financial reporting incentives. These results are stronger for firms with greater income shifting incentives (i.e., larger tax rate differentials and firms with 2016 taxable income to offset via a 2017 loss carry back) and firms subject to higher financial reporting pressure. Taken together, our findings

suggest that firms save taxes using REM by shifting taxable income from the high-tax to the low-tax period while using AEM to still report high book earnings. 
Our findings provide useful insights for policy makers, tax authorities, and academics. We update and expand the empirical insights from tax rate changes and demonstrate that tax optimization, even around a major tax reform like the TCJA, is just one piece in the complex puzzle of firms' earnings management incentives. Based on a theoretical model, we provide evidence that firms use different earnings management techniques around tax rate changes. We identify book-tax conformity as a major determinant of the use of REM and AEM around decreases in tax rates. Our findings document an unintended consequence of the TCJA suggesting that regulators should carefully weigh the costs and benefits of tax rate reductions.

This paper is subject to several caveats. First, due to the archival nature of our analyses, we are not able to establish a causal relationship between the TCJA and earnings management. However, we believe that our theoretical model-based approach, the timing of the TCJA, and consistent findings from a wide set of empirical analyses, including the specific earnings management mechanisms in the quarters immediately prior to TCJA, make it fairly unlikely that our conclusions are biased. Second, we focus on a relatively short window around the enactment of the TCJA, which is characterized by several changes of political, societal, and economic parameters. Although our research design controls for general time trends and the economic environment, we ultimately cannot rule out confounding effects. Nonetheless, we believe this study offers interesting insights into how the largest US tax reform since 1986 affects firms' earnings management behavior. 


\section{APPENDIX A}

\section{Example for the Use of Real and Accrual-Based Earnings Management around Tax Rate Reductions}

\section{Facts}

- In 2017 and 2018, the firm has $\$ 500$ of pre-managed taxable and book income (fiscal year ends on December 31).

- The firm recognizes flexibility to shift $\$ 100$ of taxable income from 2017 (tax rate of 35\%) to 2018 (tax rate of 21\%). Thus, the firm wants to lower the taxable income in 2017 by $\$ 100$ but still report $\$ 500$ in book income which is needed to meet a given earnings target.

\section{Manipulation of Taxable and Book Income}

- Pay $\$ 100$ for an advertising campaign in late-2017 that normally would be undertaken in early-2018 (abnormally high SG\&A as a form of REM).

- Delay $\$ 100$ asset impairment with zero tax basis from 2017 to 2018 for book purposes (abnormally high non-current accruals as a form of AEM).

Taxable Income, Book Income, and Taxes

\begin{tabular}{lcc}
\multicolumn{3}{c}{ Year 2017 } \\
\hline Taxable & Book & Tax \\
Income & Income & $(35 \%)$ \\
\hline
\end{tabular}

\begin{tabular}{lcc}
\multicolumn{3}{c}{ Year 2018 } \\
\hline Taxable & Book & Tax \\
Income & Income & $(21 \%)$ \\
\hline
\end{tabular}

Total Tax

Pre-managed income

Preponed an advertising campaign (REM)

Income after REM

\begin{tabular}{cc}
500 & 500 \\
$(100)$ & $(100)$ \\
\hline $\mathbf{4 0 0}$ & $\mathbf{4 0 0}$
\end{tabular}

175

\begin{tabular}{ll}
500 & 500 \\
100 & 100 \\
\hline $\mathbf{6 0 0}$ & $\mathbf{6 0 0}$
\end{tabular}

105

\begin{tabular}{cc}
0 & 100 \\
\hline $\mathbf{4 0 0}$ & $\mathbf{5 0 0}$
\end{tabular}

\begin{tabular}{cc}
0 & $(100)$ \\
\hline $\mathbf{6 0 0}$ & $\mathbf{5 0 0}$
\end{tabular}




\section{APPENDIX B \\ Definition of Earnings Management Measures}

Building on the prior literature (Roychowdhury 2006; Cohen and Zarowin 2010; Gunny 2010), this appendix provides definitions of our earnings management measures. Financial position variables (e.g., total assets) are defined as the amount at the end of the fiscal quarter and financial performance variables (e.g., sales) are defined as the value of the fiscal quarter defined based on the cumulative items provided in the COMPUSTAT database.

\section{Real Earnings Management}

\section{Abnormal Production Costs}

As a first method for upwards REM, we consider overproduction (Zang 2012). The basic intuition of this manipulation technique is that, ceteris paribus, a firm can increase income when the firm produces more units due to a decrease of the fixed overhead costs per unit because they are spread over a larger number of units. As long as the reduction in fixed overhead costs per unit is not offset by any increase in marginal costs per unit, total cost per unit declines (Roychowdhury 2006). In line with Cohen et al. (2008), we model the normal level of production costs as follows. We estimate this equation on the industry-calendar quarter level and require at least 15 observations per regression.

$$
P R O D_{i t}=\beta_{1}\left(\frac{1}{A_{i t-1}}\right)+\beta_{2} S_{i t}+\beta_{3} \Delta S_{i t}+\beta_{4} \Delta S_{i t-1}+u_{i t}
$$

$P R O D_{i t}$ is production cost, defined as cost of goods sold (\#cogs) plus the change in total inventories (\#invt), to lagged total assets (\#at). $A_{i t-1}$ is lagged total assets (\#at). $S_{i t}$ is net sales (\#sale) to lagged total assets (\#at). $\Delta S_{i t}$ is the change in net sales (\#sale) to lagged total assets (\#at). $\Delta S_{i t-1}$ is the lagged change in net sales (\#sale) to lagged total assets (\#at). Higher values of abnormal production costs $\left(A P R O D_{i t}\right)$, defined as the residual of this regression, indicate income-increasing REM.

\section{Abnormal Discretionary Expenses}

Next, we consider cutting discretionary expenses (Roychowdhury 2006). A reduction of R\&D and SG\&A expenses directly boosts current period's earnings. To provide detailed evidence, we follow Gunny (2010) and separately estimate the normal level of R\&D and SG\&A expenses using the model applied by Cohen et al. (2008). ${ }^{27}$ Again, we estimate these equations on the industry-calendar quarter level and require at least 15 observations per regression.

$$
\begin{aligned}
& R D_{i t}=\beta_{1}\left(\frac{1}{A_{i t-1}}\right)+\beta_{2} S_{i t-1}+u_{i t} \\
& S G A_{i t}=\beta_{1}\left(\frac{1}{A_{i t-1}}\right)+\beta_{2} S_{i t-1}+u_{i t}
\end{aligned}
$$

\footnotetext{
${ }^{27}$ Abnormal discretionary expenses are often estimated in a single regression, i.e., using the sum of R\&D and SG\&A expenses as the explained variable in the first-step regression (Cohen et al. 2008). To provide more detailed evidence about the techniques used for income shifting around the TCJA, we estimate separate first-step regressions (Gunny 2010). We note that our findings are virtually unaffected by this choice.
} 
$R D_{i t}$ is R\&D expenses (\#xrd) ) to lagged total assets (\#at). $S G A_{i t}$ is SG\&A expenses (\#xsga) to lagged total assets (\#at) (Gunny 2010). $S_{i t-1}$ is lagged net sales (\#sale) to lagged total assets (\#at). Higher values of abnormal $\mathrm{R} \& \mathrm{D}$ expenses $\left(A R D_{i t}\right)$, defined as the residual of Equation A.2, and higher values of abnormal SG\&A expenses $\left(A S G A_{i t}\right)$, defined as the residual of Equation A.3, indicate income-decreasing REM, respectively. In our analyses, we multiply $A R D_{i t}$ and $A S G A_{i t}$ with $(-1)$ to ease the interpretation of our findings.

\section{Aggregated Measure for Real Earnings Management}

We define an aggregated measure for income-increasing REM $\left(R E M_{i t}\right)$ as $A P R O D_{i t}$, less $A R D_{i t}$, less $A S G A_{i t}$. For our univariate analyses, we adjust $R E M_{i t}$ for a linear time trend and effects related to the end of the quarter. More specifically, we regress $R E M_{i t}$ on $T R E N D_{t}$, on four indicators for the calendar quarters $\left(\sum C Q_{i t}\right)$, and four indicators for the fiscal quarters $\left(\sum F Q_{i t}\right) . R E M_{i t}^{\text {adj }}$ is the residual of this regression.

\section{Accrual-Based Earnings Management}

\section{Total Accruals Manipulations}

In line with Cohen et al. (2008) and Zang (2012), we use discretionary accruals to proxy for AEM. We estimate the following Jones (1991) model on the industry-calendar quarter level and require at least 15 observations per regression.

$T A_{i t}=\beta_{1}\left(\frac{1}{A_{i t-1}}\right)+\beta_{2} \Delta S_{i t}+\beta_{3} P P E_{i t}+u_{i t}$

$T A_{i t}$ is total accruals, defined as net income before extraordinary items (\#ib), minus cash flow from operations (\#oancf), to lagged total assets (\#at) (Collins and Hribar 1999). $\Delta S_{i t}$ is the change in net sale (\#sale) to lagged total assets (\#at). PPE $E_{i t}$ is net property, plant, and equipment

(\#ppent) to lagged total assets (\#at). For our univariate analyses, we adjust $A E M_{i t}$ for a linear time trend and effects related to the end of the quarter. More specifically, we regress $A E M_{i t}$ on $T R E N D_{t}$, on four indicators for the calendar quarters $\left(\sum C Q_{i t}\right)$, and four indicators for the fiscal quarters $\left(\sum F Q_{i t}\right) . A E M_{i t}^{\text {adj }}$ is the residual of this regression.

\section{Current and Non-Current Accruals Manipulations}

Following Guenther (1994), we note that total accruals consist of current accruals and non-current accruals. We approximate current accruals $\left(C A_{i t}\right)$ as the change in current assets (\#act), minus the change in cash and cash equivalents (\#che), minus the change in current liabilities (\#lct), plus the change in debt in current liabilities (\#dlc), plus change in tax payables (\#txp), to lagged total assets (\#at). Substituting $T A_{i t}$ with $C A_{i t}$ in Equation A.4, our empirical proxy for abnormal current accruals $\left(A C A_{i t}\right)$ is the residual of this regression. Then, we calculate abnormal non-current accruals $\left(A N C A_{i t}\right)$ as the difference between $A E M_{i t}$ and $A C A_{i t}$. 


\section{APPENDIX C Definitions of Control Variables}

This appendix provides definitions of our control variables. Similar to Appendix B, financial position variables (e.g., total assets) are defined as the amount at the end of the fiscal quarter and financial performance variables (e.g., sales) are defined as the value of the fiscal quarter defined based on the cumulative items provided in the COMPUSTAT database.

ASSETS $_{i t} \quad$ Industry-adjusted firm size (Zang 2012), defined as the industry-adjusted natural logarithm of total assets (\#at).

BIGFOUR $_{i t} \quad$ Indicator that takes a value of 1 if the yearly financial reports is audited by a big four audit firm, (calculated based on the item \#au from the annual file).

CYCLE $\quad$ Operating cycle (Dechow 1994), defined as the mean trade receivables (\#rectr) at the beginning and end of the quarter to sales (\#sale), plus mean total inventories (\#invt) at the beginning and end of the quarter to costs of goods sold (\# $\operatorname{cog} s)$, multiplied by 360, and annualized through division with four.

$E A R N_{i t}$

Unmanaged return on assets (Zang 2012) (in \%), defined as return on assets $\left(R O A_{i t}\right)$, minus abnormal production costs $\left(A P R O D_{i t}\right)$, plus abnormal $\mathrm{R} \& \mathrm{D}$ expenses $\left(A R D_{i t}\right)$, plus abnormal SG\&A expenses $\left(A S G A_{i t}\right)$, minus discretionary accruals $\left(A E M_{i t}\right)$ as defined in Appendix $\mathrm{B}$, to lagged total assets (\#at).

$E_{C O N}{ }_{t}^{\text {growth }} \quad$ US real gross domestic product growth, defined as the yearly change in the gross domestic product less the inflation rate of the calendar year.

$E_{C O N}{ }_{t}^{\text {ret }} \quad$ Calendar year return of the S\&P 500 stock index.

$E_{C O N}{ }_{t}^{\text {vol }} \quad$ Economy-wide stock trading volume, defined as the value of domestic shares traded divided by their market capitalization of the calendar year.

HABITUAL $L_{i t} \quad$ Indicator that takes a value of 1 if the firm is a "habitual earnings target beater" (Bartov et al. 2002) defined as a firm has a suspect quarter in more than 3 quarters (upper quartile of the sample distribution) over the prior 12 fiscal quarters (Lynch et al. 2019). We define a fiscal quarter to be suspect for earnings management to meet/beat earnings targets when the earnings per share (obtained from IBES), (i) are larger or equal to zero and do not exceed 1 cent, and/or (ii) exceed the earnings per share in the same fiscal quarter in the previous fiscal year and do not exceed them by more than one cent, and/or (iii) exceed the last earnings per share financial analyst consensus forecast available prior to the end of the fiscal quarter and do not exceed it by more than one cent.

$M T B_{i t} \quad$ Market value (\#mkvalt) to book value of common equity (\#ceq) at the end of the quarter.

$N O A_{i t} \quad$ Net operating assets (Barton and Simko 2002), defined as book value of equity (\#ceq), less cash and cash equivalents (\#che), plus total debt (\#dlc plus \#dltt), to sales in the previous quarter (\#sale).

$R O A_{i t} \quad$ Return on assets (in \%), defined as earnings before interest and taxes (\#pi plus \#xint) to lagged total assets (\#at).

$S H A R E_{i t} \quad$ Sales-market share of the firm, defined as sales of the firm (\#sale) to total sales of the industry.

TENURE $_{i t} \quad$ Audit tenure, defined as the number of years the auditor has audited the financial reports of the firm (calculated based on the item \#au from the annual file).

$T_{i t} \quad$ Taxable income to lagged total assets (\#at). Taxable income is the sum of the federal tax expense (\#txfed) and current foreign tax expense (\#txfo), to the statutory tax rate as reported in Table 2, minus the change in net operating loss carryforwards (\#tlcf) (Kim et al. 2011). If the current federal tax expense is missing, then total current tax expenses is calculated as the difference between total income taxes (\#txt) and the sum of deferred taxes (\#txdi), state income taxes (\#txs), and other income taxes (\#txo) (Hoi et al. 2013).

TREND $\quad$ Linear time trend, defined as the difference between the number of the current calendar quarter and the first calendar quarter of 2010.

ZSCORE $_{\text {it }} \quad$ Z-score for financial health (Altman 1968), defined as $1.2 \times$ working capital (\#wcap) to total assets (\#at), plus $1.4 \times$ retained earnings (\#re) to total assets $(\# a t)$, plus $3.3 \times$ earnings before interest and taxes (\#pi minus \#xint) to total assets (\#at) $\times 4$ (annualized), plus $0.6 \times$ market value of equity (\#mkvalt) to total liabilities (\#dltt plus \#lct), plus $1.0 \times$ sales (\#sale) to total assets (\#at). 


\section{REFERENCES}

Altman, E. 1968. Financial ratios, discriminate analysis, and the prediction of corporate bankruptcy. Journal of Finance 23: 589-609.

Andries, K., M. Cools, and S. van Uytbergen. 2017. To shift or not to shift? Intertemporal income shifting as a response to the risk capital allowance introduction in Belgium. European Accounting Review 26: 531-559.

Barton, J., and P. J. Simko. 2002. The balance sheet as an earnings management constraint. Accounting Review 77: 1-27.

Bartov, E., D. Givoly, and C. Hayn. 2002. The rewards to meeting or beating earnings expectations. Accounting Review 33: 173-204.

BDO. 2018. Tax reform impacts the research tax credit, domestic production activities deduction, and orphan drug credit. Available at: https:/www.bdo.com/insights/tax/federal-tax/tax-reform-impacts-the-research-taxcredit,-domest.

Beatty, A., S. Chamberlain, and J. Magliolo. 1995. Managing financial reports of commercial banks: The influence of taxes regulatory capital, and earnings. Journal of Accounting Research 33: 231-261.

Becker, C., M. DeFond, J. Jiambalvo, and K. R. Subramanyam. 1998. The effect of audit quality on earnings management. Contemporary Accounting Research 15: 1-24.

Boynton, C., P. Dobbins, and G. Plesko. 1992. Earnings management and the corporate alternative minimum tax. Journal of Accounting Research 30: 131-160.

Burgstahler, D., and I. Dichev. 1997. Earnings management to avoid earnings decreases and losses. Journal of Accounting and Economics 24: 99-126.

Bushee, B. 1998. The influence of institutional investors on myopic R\&D investment behavior. Accounting Review 73: 305-333.

Carrizosa, R., F. B. Gaertner, and D. Lynch. 2020. Debt and taxes? The effect of TCJA interest limitations on capital structure. Working paper, University of Wisconsin, US.

Cheng, Q., and T. D. Warfield. 2005. Equity incentives and earnings management. Accounting Review 80: 441476.

Chen, W. E. I., Hribar, P., \& Melessa, S. 2018. Incorrect inferences when using residuals as dependent variables. Journal of Accounting Research, 56(3), 751-796.

Cohen, D. A., A. Dey, and T. Z. Lys. 2008. Real and accrual-based earnings management in the pre- and postSarbanes-Oxley periods. Accounting Review 83: 757-787.

Cohen, D. A., and P. Zarowin. 2010. Accrual-based and real earnings management activities around seasoned equity offerings. Journal of Accounting and Economics 50: 2-19.

Collins, D. W., and P. Hribar. 1999. Earnings-based and accrual-based market anomalies: One effect or two? Journal of Accounting and Economics 29: 101-123.

Collins, J., D. Kemsley, and M. Lang. 1998. Cross-jurisdictional income shifting and earnings valuation. Journal of Accounting Research 36: 209-229.

Congressional Budget Office (CBO). 2018. How the 2017 tax act affects CBO's projections. Available at: https://www.cbo.gov/publication/53787.

Cotter, J., I. Tuna, and P. D. Wysocki. 2006. Expectation management and beatable targets: How do analysts react to explicit earnings guidance. Contemporary Accounting Research 23: 593-624.

Christensen, H. B., L. Hail, and C. Leuz. 2016. Capital-market effects of securities regulation: Prior conditions, implementation, and enforcement. Review of Financial Studies 29: 2885-2924.

Cushing, B. E., and M. J. LeClere. 1992. Evidence on the determinants of inventory accounting policy choice. Accounting Review 67: 355-366.

De Simone, L. 2016. Does a common set of accounting standards affect tax-motivated income shifting for multinational firms? Journal of Accounting and Economics 61: 145-165.

Dechow, P. M. 1994. Accounting earnings and cash flows as measures of firm performance: The role of accounting accruals. Journal of Accounting and Economics 18: 3-42.

Dechow, P. M., S. A. Richardson, and I. Tuna. 2003. Why are earnings kinky? An examination of the earnings management explanation. Review of Accounting Studies 8: 355-384. 
Dechow, P. M., R. G. Sloan, and A. P. Sweeney. 1995. Detecting earnings management. Accounting Review 70: 193-225.

Dechow, P. M., and I. D. Dichev. 2002. The quality of accruals and earnings: The role of accrual estimation errors. Accounting Review 77: 35-59.

Desai, M.A., and D. Dharmapala. 2006. Corporate tax avoidance and high-powered incentives. Journal of Financial Economics 79: 145-179.

Dhaliwal, D., and S. Wang. 1992. The effect of book income adjustment in the 1986 alternative minimum tax on corporate financial reporting. Journal of Accounting and Economics 15: 7-26.

Dharmapala, D. 2018. The consequences of the TCJA's international provisions: Lessons from existing research. National Tax Journal 71: 707-728.

Donohoe, M. P., G. A. McGill, and E. Outslay. 2019. The geometry of international tax planning after the TCJA: A riff on circles, squares, and triangles. National Tax Journal 72: 647-670.

Ernstberger, J., B. Link, M. Stich, and O. Vogler. 2017. The real effects of mandatory quarterly reporting. Accounting Review 92: 33-60.

Ewert, R., and A. Wagenhofer. 2005. Economic effects of tightening accounting standards to restrict earnings management. Accounting Review 80: 1101-1124.

Gaertner, F. B., J. L. Hoopes, and B. M. Williams. 2020. Making only America great? Non-US market reactions to US tax reform. Management Science 66: 503-1004.

Gale, W. G., H. Gelfond, A. Krupkin, M. J. Mazur, and E. J. Toder. 2019. Effects of the TCJA: A preliminary analysis. National Tax Journal 71: 589-612.

Graham, J. R., C. R. Harvey, and S. Rajgopal. 2005. The economic implications of corporate financial reporting. Journal of Accounting and Economics 40: 3-73.

Guenther, D. A. 1994. Earnings management in response to corporate tax rate changes: Evidence from the 1986 TRA. Accounting Review 69: 230-243.

Guenther, D. A., E. Maydew, and S. Nutter. 1997. Financial reporting, tax costs, and book-tax conformity. Journal of Accounting and Economics 23: 225-248.

Gunny, K. A. 2010. The relation between earnings management using real activities manipulation and future performance: Evidence from meeting earnings benchmarks. Contemporary Accounting Research 27: 855-888.

Hanlon, M., and S. Heitzman. 2010. A review of tax research. Journal of Accounting and Economics 50: $127-178$.

Hoi, C. K., Q. Wu, and H. Zhang. 2013. Is corporate social responsibility (CSR) associated with tax avoidance? Evidence from irresponsible CSR activities. Accounting Review 88: 2025-2059.

Huizinga, H., and L. Laeven. 2008. International profit shifting within multinationals: A multi-country perspective. Journal of Public Economics 92: 1164-1182.

Huizinga, H., L. Laeven, and G. Nicodeme. 2008. Capital structure and international debt shifting. Journal of Financial Economics 88: 80-118.

Internal Revenue Service (IRS). 2019. About publication 538: Accounting periods and methods. Available at: https://www.irs.gov/forms-pubs/about-publication-538.

Johnson, W. B., and D. S. Dhaliwal. 1988. LIFO abandonment. Journal of Accounting Research 26: $236-272$.

Jones, J. J. 1991. Earnings management during import relief investigations. Journal of Accounting Research 29: 193-228.

Kanodia, C., and H. Sapra. 2016. A real effects perspective to accounting measurement and disclosure: Implications and insights for future research. Journal of Accounting Research 54: 623-676.

Kim, J.-B., Y. Li, and L. Zhang. 2011. Corporate tax avoidance and stock price crash risk: Firm-level analysis. Journal of Financial Economics 100: 639-662.

King, Z., D. Lynch, B. Stromberg, and S. Utke. 2020. Does financial reporting for income tax expense affect the timeliness of goodwill impairments? Working paper, University of Wisconsin, Madison, WI.

Klassen, K. J., and S. K. Laplante. 2012. Are US multinational corporations becoming more aggressive income shifters? Journal of Accounting Research 50: 1245-1285.

Kothari, S. P., A. Leone, and C. E. Wasley. 2005. Performance matched discretionary accrual measures. Journal of Accounting and Economics 39: 163-197. 
Koutney, C. Q., and L. F. Mills. 2018. The immediate impact of tax reform on corporate earnings: Investor expectations and reactions. Working paper, George Mason University, Fairfax, VA.

Lin, B., R. Lu, and T. Zhang. 2012. Tax-induced earnings management in emerging markets: Evidence from China. Journal of the American Taxation Association 34: 19-44.

Lopez, T. J., P. R. Regier, and T. Lee. 1998. Identifying tax-induced earnings management around TRA 86 as a function of prior tax-aggressive behavior. Journal of the American Taxation Association 20: 37-56.

Lynch, D., M. Romney, B. Stomberg, D. Wangerin, and J. R. Robinson. 2019. Trade-offs between tax and financial reporting benefits: Evidence from purchase price allocations in taxable acquisitions. Contemporary Accounting Research 36: 1223-1262.

Matsumoto, D. 2002. Management's incentives to avoid negative earnings surprises. Accounting Review 77: 483514.

Matsunaga, S., T. Shevlin, and D. Shores. 1992. Disqualifying dispositions of incentive stock options: Tax benefits versus financial reporting costs. Journal of Accounting Research 30: 37-76.

Maydew, E. L. 1997. Tax-induced earnings management by firms with net operating losses. Journal of Accounting Research 35, 83-96.

Myers, J. N., L. A. Myers, and T. C. Omer. 2003. Exploring the term of the auditor-client relationship and the quality of earnings: A case for mandatory auditor rotation? Accounting Review 78: 779-799.

Randolph, D. W., G. L. Salamon, and J. A. Seida. 2005. Quantifying the costs of intertemporal taxable income shifting: Theory and evidence from the property-casualty insurance industry. Accounting Review 80: 315-348.

Richardson, S., S. Teoh, and P. Wysocki. 2004. The walk-down to beatable analyst forecasts: The roles of equity issuance and insider-trading incentives. Contemporary Accounting Research 21: 885-924.

Roychowdhury, S. 2006. Earnings management through real activities manipulation. Journal of Accounting and Economics 42: 335-370.

Scholes, M. S., and M. A. Wolfson. 1992. Taxes and business strategy: A planning approach.

Scholes, M. S., G. P. Wilson, and M. A. Wolfson. 1990. Tax planning, regulatory capital planning, and financial reporting strategy for commercial banks. Review of Financial Studies 3: 625-650.

Scholes, M. S., G. P. Wilson, and M. A. Wolfson. 1992. Firms' responses to anticipated reductions in tax rates: The TRA of 1986. Journal of Accounting Research 30: 161-185.

Shackelford, D. A., and T. Shevlin. 2001. Empirical tax research in accounting. Journal of Accounting and Economics 31: 321-387.

Shane, P. B., and T. Stock. 2006. Security analyst and stock market efficiency in anticipating tax-motivated income shifting. Accounting Review 81: 227-250.

Slemrod, J. 2018. Tax reform and tax experts. Journal of the American Taxation Association 40: 83-88.

Vorst, P. 2016. Real earnings management and long-term operating performance: The role of reversals in discretionary investment cuts. Accounting Review 91: 1219-1256.

Wagner, A. F., R. J. Zeckhauser, and A. Ziegler. 2018a. Company stock price reactions to the 2016 election shock: Trump, taxes, and trade. Journal of Financial Economics 130: 428-451.

Wagner, A. F., R. J. Zeckhauser, and A. Ziegler. 2018b. Unequal rewards to firms: Stock market responses to the Trump election and the 2017 corporate tax reform. American Economic Association Papers and Proceedings 108: 590-596.

Zang, A. Y. 2012. Evidence on the trade-off between real activities manipulations and accrual-based earnings management. Accounting Review 87: 675-703. 


\section{FIGURE 1}

\section{Timeline of the Passage of the 'Tax Cuts and Jobs Act'}

\begin{tabular}{|c|c|c|c|c|c|c|c|}
\hline $\begin{array}{c}\text { Nov } 08, \\
2016\end{array}$ & $\begin{array}{c}\text { Sep 27, } \\
2017\end{array}$ & $\begin{array}{c}\text { Nov 02, } \\
2017\end{array}$ & $\begin{array}{c}\text { Nov 16, } \\
2017\end{array}$ & $\begin{array}{c}\text { Dec 02, } \\
2017\end{array}$ & $\begin{array}{c}\text { Dec 15, } \\
2017\end{array}$ & $\begin{array}{c}\text { Dec 20, } \\
2017\end{array}$ & $\begin{array}{c}\text { Jan 01, } \\
2018\end{array}$ \\
\hline $\mid$ & 1 & 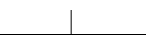 & 1 & 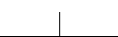 & $\downarrow$ & 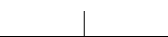 & 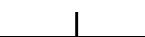 \\
\hline 1 & & & & & & & \\
\hline $\begin{array}{l}\text { Election } \\
\text { of Donald } \\
\text { J. Trump }\end{array}$ & $\begin{array}{c}\text { Introduction } \\
\text { of a tax } \\
\text { reform }\end{array}$ & $\begin{array}{l}\text { Bill } \\
\text { introduced to } \\
\text { the House }\end{array}$ & $\begin{array}{c}\text { House } \\
\text { bill passed }\end{array}$ & $\begin{array}{c}\text { Senate } \\
\text { bill passed }\end{array}$ & $\begin{array}{c}\text { Agreement } \\
\text { passed and } \\
\text { published }\end{array}$ & $\begin{array}{c}\text { Bill signed into } \\
\text { law by the US } \\
\text { President }\end{array}$ & $\begin{array}{c}\text { Effectiveness } \\
\text { of the law }\end{array}$ \\
\hline
\end{tabular}

Notes: This figure summarizes the timeline of the development and enactment of the TCJA. For more details about the key dates in the passage of the TCJA see Gaertner et al. (2020). 
FIGURE 2

Earnings Management around the Enactment of the 'Tax Cuts and Jobs Act'

\section{Panel A: Calendar Year Mean Earnings Management}

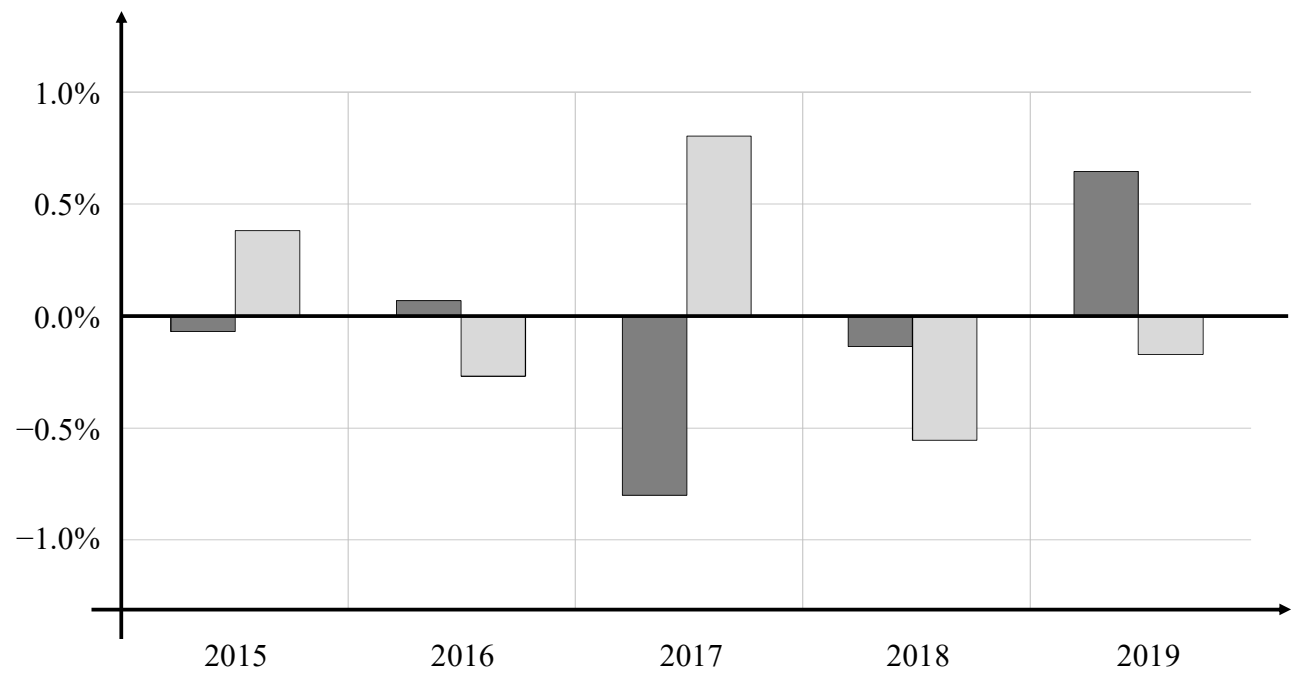

\section{Panel B: Calendar Quarter Mean Earnings Management}

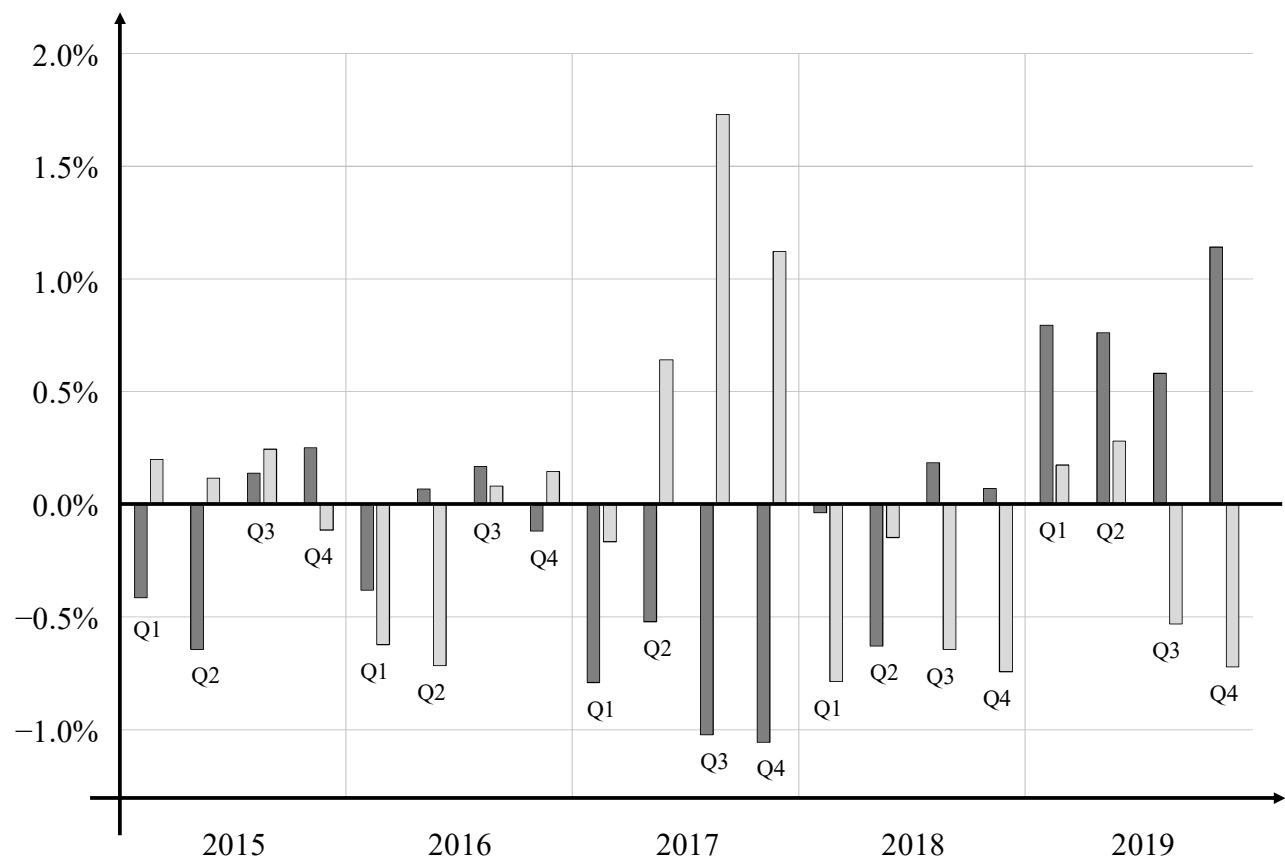

Notes: This figure shows the calendar year means (Panel A) and the calendar quarter means (Panel B) of REM adjusted for a linear time trend and effects related to the end of quarter $\left(R E M_{i t}^{\text {adj }}\right)$ in dark grey columns and calendar year means (Panel A) and calendar quarter means (Panel B) of AEM adjusted for a linear time trend and effects related to the end of quarter $\left(A E M_{i t}^{\text {adj }}\right)$ in light grey columns as defined in Appendix B. Measures are winsorized at the $1^{\text {st }}$ and $99^{\text {th }}$ percentile, respectively. 


\section{TABLE 1}

\section{Sample Selection}

\begin{tabular}{|c|c|c|}
\hline & $\begin{array}{l}\text { Firm-quarter } \\
\text { observations }\end{array}$ & $\begin{array}{c}\text { Firm } \\
\text { observations }\end{array}$ \\
\hline $\begin{array}{l}\text { US firms (\#fic) with net sales (\#sale) available in the quarterly file } \\
\text { of the COMPUSTAT database during the investigation interval } \\
\text { from the calendar year } 2010 \text { to } 2019 \text {. }\end{array}$ & 229,929 & 9,358 \\
\hline $\begin{array}{l}\text { Less observations that refer to fiscal years with a length unequal to } 12 \text { months } \\
\text { and fiscal quarters with a length unequal to } 3 \text { months (\#pddur and \#datadate). }\end{array}$ & 8,988 & 469 \\
\hline $\begin{array}{l}\text { Less observations of firms from the financial and insurance industry (SIC } 6000 \text { to 6999) } \\
\text { and from regulated industries (SIC } 4400 \text { to } 4999 \text { ) (\#sic). } \\
\text { We also eliminate firms without SIC classification. }\end{array}$ & 69,784 & 2,527 \\
\hline Less observation of firms with total assets lower than $\$ 1$ million. & 16,920 & 423 \\
\hline $\begin{array}{l}\text { Less observations with missing data and firms with less than } 10 \text { observations } \\
\text { over the investigation period from the calendar year } 2010 \text { to } 2019 \text {. }\end{array}$ & 113,016 & 5,088 \\
\hline Final sample & 21,221 & 851 \\
\hline
\end{tabular}

Notes: This table summarizes the steps of the sample selection. For each step, the table shows the number of firm-quarter observations and the number of firm observations eliminated. Data items refer to the quarterly file of the COMPUSTAT database. 
TABLE 2

Statutory Tax Rates and Tax Saving Rates

\begin{tabular}{|c|c|c|c|}
\hline Fiscal Year End & $\begin{array}{c}\text { Statutory Tax Rate } \\
\text { in the Current } \\
\text { Fiscal Year }\end{array}$ & $\begin{array}{l}\text { Tax Rate } \\
\text { in the Next } \\
\text { Fiscal Year }\end{array}$ & Tax Saving Rate \\
\hline December 2016 (and earlier) & 0.350 & 0.350 & 0.000 \\
\hline January 2017 & 0.350 & 0.338 & 0.012 \\
\hline February 2017 & 0.350 & 0.327 & 0.023 \\
\hline March 2017 & 0.350 & 0.315 & 0.035 \\
\hline April 2017 & 0.350 & 0.304 & 0.046 \\
\hline May 2017 & 0.350 & 0.292 & 0.058 \\
\hline June 2017 & 0.350 & 0.281 & 0.069 \\
\hline July 2017 & 0.350 & 0.269 & 0.081 \\
\hline August 2017 & 0.350 & 0.257 & 0.093 \\
\hline September 2017 & 0.350 & 0.245 & 0.105 \\
\hline October 2017 & 0.350 & 0.233 & 0.117 \\
\hline November 2017 & 0.350 & 0.222 & 0.128 \\
\hline December 2017 & 0.350 & 0.210 & 0.140 \\
\hline January 2018 & 0.338 & 0.210 & 0.128 \\
\hline February 2018 & 0.327 & 0.210 & 0.117 \\
\hline March 2018 & 0.315 & 0.210 & 0.105 \\
\hline April 2018 & 0.304 & 0.210 & 0.094 \\
\hline May 2018 & 0.292 & 0.210 & 0.082 \\
\hline June 2018 & 0.281 & 0.210 & 0.071 \\
\hline July 2018 & 0.269 & 0.210 & 0.059 \\
\hline August 2018 & 0.257 & 0.210 & 0.047 \\
\hline September 2018 & 0.245 & 0.210 & 0.035 \\
\hline October 2018 & 0.233 & 0.210 & 0.023 \\
\hline November 2018 & 0.222 & 0.210 & 0.012 \\
\hline December 2018 (and later) & 0.210 & 0.210 & 0.000 \\
\hline
\end{tabular}

Notes: This table shows the statutory corporate tax rate in the current fiscal year, the anticipated tax rate in the next fiscal year, and the anticipated tax saving rate for firms with different fiscal year ends. 
TABLE 3

\section{Descriptive Statistics}

Panel A: Earnings Management Measures

\begin{tabular}{lrrrrrr} 
& Mean & $\begin{array}{c}\text { Standard } \\
\text { Deviation }\end{array}$ & $\begin{array}{c}\text { Lower } \\
\text { Quartile }\end{array}$ & Median & $\begin{array}{c}\text { Upper } \\
\text { Quartile }\end{array}$ & $\begin{array}{c}\text { Firm- } \\
\text { Quarters }\end{array}$ \\
\cline { 2 - 6 } & & & & & & \\
\\
$R E M_{i t}$ & -1.253 & 11.243 & -7.170 & -1.216 & 4.309 & 21,221 \\
$A P R O D_{i t}$ & -0.564 & 4.755 & -3.306 & -0.869 & 1.757 & 21,221 \\
$A R D_{i t} \times(-1)$ & -0.411 & 2.433 & -1.313 & 0.000 & 0.587 & 21,221 \\
$A S G A_{i t} \times(-1)$ & -0.303 & 5.983 & -2.959 & 0.038 & 2.403 & 21,221 \\
$A E M_{i t}$ & 0.170 & 5.784 & -2.207 & -0.229 & 2.008 & 21,221 \\
$A C A_{i t}$ & 0.090 & 4.425 & -1.652 & 0.032 & 1.746 & 21,221 \\
$A N C A_{i t}$ & 0.093 & 4.934 & -1.664 & -0.300 & 1.279 & 21,221
\end{tabular}

\section{Panel B: Control Variables}

\begin{tabular}{|c|c|c|c|c|c|c|}
\hline & Mean & $\begin{array}{l}\text { Standard } \\
\text { Deviation }\end{array}$ & $\begin{array}{c}\text { Lower } \\
\text { Quartile }\end{array}$ & Median & $\begin{array}{c}\text { Upper } \\
\text { Quartile }\end{array}$ & $\begin{array}{c}\text { Firm- } \\
\text { Quarters }\end{array}$ \\
\hline$S H A R E_{i t-1}$ & 0.012 & 0.034 & 0.000 & 0.001 & 0.007 & 21,221 \\
\hline $\operatorname{ZSCORE}_{i t-1}$ & 4.803 & 9.205 & 1.835 & 3.783 & 6.571 & 21,221 \\
\hline$I N S T_{i t-1}$ & 0.637 & 0.332 & 0.362 & 0.744 & 0.907 & 21,221 \\
\hline BIGFOUR $_{i t}$ & 0.668 & 0.471 & 0.000 & 1.000 & 1.000 & 21,221 \\
\hline$T_{E N U R E_{i t}}$ & 8.866 & 5.648 & 4.000 & 9.000 & 13.000 & 21,221 \\
\hline$C Y C L E_{i t-1}$ & 157.637 & 125.389 & 78.229 & 136.082 & 196.736 & 21,221 \\
\hline$N O A_{i t-1}$ & 0.687 & 0.643 & 0.298 & 0.557 & 0.932 & 21,221 \\
\hline$R O A_{i t}$ & 0.379 & 5.493 & -0.992 & 1.484 & 3.173 & 21,221 \\
\hline$M T B_{i t}$ & 3.910 & 7.642 & 1.443 & 2.635 & 4.735 & 21,221 \\
\hline ASSETS $_{i t}$ & 0.000 & 2.175 & -1.475 & 0.042 & 1.508 & 21,221 \\
\hline$E A R N_{i t}$ & 1.470 & 13.690 & -4.402 & 2.555 & 9.132 & 21,221 \\
\hline $\operatorname{CCON}_{t}^{\text {growth }}$ & 2.285 & 0.461 & 1.875 & 2.294 & 2.594 & 21,221 \\
\hline$E \operatorname{CON}_{t}^{\mathrm{ret}}$ & 11.635 & 11.262 & -0.003 & 11.391 & 19.420 & 21,221 \\
\hline $\operatorname{ECON}_{t}^{\mathrm{vol}}$ & 151.712 & 48.288 & 115.418 & 138.329 & 173.285 & 21,221 \\
\hline
\end{tabular}

Notes: Panel A shows descriptive statistics for our compound REM and AEM measures, adjusted compound REM and AEM measures, and the REM components as defined in Appendix B. All REM and AEM measures are defined that higher values indicate income-increasing earnings management (in percent). Panel B shows descriptive statistics for our control variables as defined in Appendix C. All continuous variables are winsorized at the $1^{\text {st }}$ and $99^{\text {th }}$ percentile, respectively. 


\begin{tabular}{|c|c|c|c|c|c|c|c|c|c|c|c|c|c|c|c|c|c|c|c|}
\hline \multicolumn{20}{|c|}{$\begin{array}{c}\text { TABLE } 4 \\
\text { Correlations }\end{array}$} \\
\hline & & (a) & (b) & (c) & (d) & (e) & (f) & (g) & (h) & (i) & (j) & (k) & (l) & (m) & (n) & (o) & (p) & (q) & $(\mathrm{r})$ \\
\hline$R E M_{i t}$ & (a) & & $0.99^{*}$ & $0.22 *$ & $0.21 *$ & $0.07^{*}$ & $-0.12 *$ & $-0.14 *$ & $-0.16^{*}$ & $-0.04 *$ & $-0.13^{*}$ & $0.05^{*}$ & $0.11^{*}$ & $-0.24^{*}$ & 0.00 & $-0.84^{*}$ & 0.01 & 0.02 & $-0.03 *$ \\
\hline$R E M_{i t}^{\text {adj }}$ & (b) & $0.99 *$ & & $0.21^{*}$ & $0.21^{*}$ & $0.07^{*}$ & $-0.12 *$ & $-0.14 *$ & $-0.16^{*}$ & $-0.04 *$ & $-0.13^{*}$ & $0.04 *$ & $0.12^{*}$ & $-0.25^{*}$ & 0.00 & $-0.83^{*}$ & 0.00 & $0.02 *$ & -0.01 \\
\hline$A E M_{i t}$ & (c) & $0.22^{*}$ & $0.22 *$ & & $0.99^{*}$ & $-0.04^{*}$ & -0.00 & $-0.11^{*}$ & $-0.11^{*}$ & $-0.05^{*}$ & $0.03^{*}$ & -0.02 & $0.15^{*}$ & $-0.07^{*}$ & $-0.05^{*}$ & $-0.47^{*}$ & 0.00 & 0.01 & 0.01 \\
\hline$A E M_{i t}^{\text {adj }}$ & (d) & $0.22 *$ & $0.22 *$ & $0.99 *$ & & $-0.04^{*}$ & 0.00 & $-0.12^{*}$ & $-0.11^{*}$ & $-0.05 *$ & $0.03 *$ & $-0.02 *$ & $0.16^{*}$ & $-0.08^{*}$ & $-0.05^{*}$ & $-0.46^{*}$ & -0.00 & 0.01 & $0.04 *$ \\
\hline$S H A R E_{i t-1}$ & (e) & $0.05^{*}$ & $0.05^{*}$ & -0.01 & -0.01 & & $0.11^{*}$ & $0.56^{*}$ & $0.58^{*}$ & $0.53 *$ & $-0.18^{*}$ & $0.19^{*}$ & $0.44 *$ & $0.13^{*}$ & $0.86^{*}$ & $0.12^{*}$ & -0.00 & 0.01 & 0.01 \\
\hline $\operatorname{ZSCORE}_{i t-1}$ & (f) & $-0.11^{*}$ & $-0.11^{*}$ & $-0.04^{*}$ & $-0.04 *$ & -0.01 & & $0.21^{*}$ & $0.11^{*}$ & $0.12 *$ & $0.03 *$ & $0.02 *$ & $0.39 *$ & $0.31^{*}$ & $0.13^{*}$ & $0.24 *$ & 0.00 & $-0.02 *$ & $0.09 *$ \\
\hline$I N S T_{i t-1}$ & (g) & $-0.18^{*}$ & $-0.18^{*}$ & $-0.13^{*}$ & $-0.13^{*}$ & $0.15^{*}$ & $0.24 *$ & & $0.56^{*}$ & $0.47^{*}$ & $-0.06^{*}$ & $0.20^{*}$ & $0.25^{*}$ & $0.25^{*}$ & $0.65^{*}$ & $0.25^{*}$ & $0.03 *$ & 0.01 & $-0.08^{*}$ \\
\hline BIGFOUR $_{i t}$ & (h) & $-0.18^{*}$ & $-0.18^{*}$ & $-0.10^{*}$ & $-0.10^{*}$ & $0.22^{*}$ & $0.11 *$ & $0.62^{*}$ & & $0.54^{*}$ & $-0.10^{*}$ & $0.13^{*}$ & $0.19^{*}$ & $0.21 *$ & $0.65^{*}$ & $0.24 *$ & -0.01 & 0.01 & $0.03 *$ \\
\hline$T E N U R E_{i t}$ & (i) & $-0.06^{*}$ & $-0.06^{*}$ & $-0.07^{*}$ & $-0.07^{*}$ & $0.22 *$ & $0.11^{*}$ & $0.51^{*}$ & $0.54 *$ & & 0.00 & $0.16^{*}$ & $0.24 *$ & $0.15^{*}$ & $0.56^{*}$ & $0.14^{*}$ & $0.04 *$ & 0.01 & $-0.14^{*}$ \\
\hline$C Y C L E_{i t-1}$ & (j) & $-0.14 *$ & $-0.14 *$ & 0.01 & 0.01 & $-0.09 *$ & $0.02 *$ & $-0.09 *$ & $-0.11 *$ & $-0.03 *$ & & $0.26^{*}$ & $-0.06^{*}$ & $-0.04 *$ & $-0.02 *$ & $0.08 *$ & 0.00 & 0.00 & -0.015 \\
\hline$N O A_{i t-1}$ & (k) & $0.03 *$ & $0.03 *$ & $-0.04 *$ & $-0.05^{*}$ & $0.02 *$ & $0.07 *$ & $0.14 *$ & $0.09 *$ & $0.11 *$ & $0.26^{*}$ & & $0.08^{*}$ & $-0.09 *$ & $0.36^{*}$ & 0.00 & 0.02 & $0.03 *$ & $-0.09^{*}$ \\
\hline$R O A_{i t}$ & (1) & $0.16^{*}$ & $0.16^{*}$ & $0.20^{*}$ & $0.20^{*}$ & $0.16^{*}$ & $0.34^{*}$ & $0.29^{*}$ & $0.21^{*}$ & $0.23^{*}$ & $-0.13^{*}$ & $0.05^{*}$ & & $0.16^{*}$ & $0.38^{*}$ & $0.18^{*}$ & $-0.02 *$ & -0.00 & $0.11^{*}$ \\
\hline$M T B_{i t}$ & (m) & $-0.14 *$ & $-0.14 *$ & $-0.05^{*}$ & $-0.05^{*}$ & -0.00 & $0.13^{*}$ & $0.11^{*}$ & $0.09 *$ & $0.04 *$ & -0.01 & $-0.07 *$ & -0.00 & & $0.21^{*}$ & $0.27 *$ & $0.06^{*}$ & -0.01 & $-0.12 *$ \\
\hline ASSETS $_{i t}$ & (n) & $-0.07^{*}$ & $-0.07 *$ & $-0.10^{*}$ & $-0.10^{*}$ & $0.48^{*}$ & $0.17^{*}$ & $0.69^{*}$ & $0.64 *$ & $0.55^{*}$ & $-0.06^{*}$ & $0.27^{*}$ & $0.40^{*}$ & $0.07 *$ & & $0.15^{*}$ & 0.00 & 0.00 & -0.00 \\
\hline$E A R N_{i t}$ & (o) & $-0.84 *$ & $-0.84^{*}$ & $-0.52^{*}$ & $-0.51^{*}$ & $0.03^{*}$ & $0.24^{*}$ & $0.32 *$ & $0.27^{*}$ & $0.16^{*}$ & $0.07 *$ & $0.02 *$ & $0.19^{*}$ & $0.14^{*}$ & $0.25^{*}$ & & -0.01 & -0.02 & $0.06^{*}$ \\
\hline$E \operatorname{CON}_{t}^{\text {growth }}$ & (p) & 0.01 & -0.00 & 0.01 & 0.00 & -0.01 & 0.02 & $0.03^{*}$ & -0.01 & $0.04 *$ & 0.01 & $0.02 *$ & -0.02 & $0.03 *$ & 0.00 & -0.01 & & $-0.36^{*}$ & $-0.03^{*}$ \\
\hline$E \operatorname{CON}_{t}^{\mathrm{ret}}$ & (q) & $0.02 *$ & $0.02 *$ & 0.01 & 0.01 & 0.01 & $-0.03^{*}$ & $0.02 *$ & 0.01 & $0.03 *$ & -0.00 & $0.03 *$ & -0.00 & $0.02 *$ & 0.00 & $-0.03^{*}$ & $0.08^{*}$ & & $-0.03^{*}$ \\
\hline$E \operatorname{CON}_{t}^{\mathrm{vol}}$ & (r) & $-0.02^{*}$ & -0.01 & -0.01 & 0.01 & 0.01 & $0.03^{*}$ & $-0.08^{*}$ & $0.03^{*}$ & $-0.15^{*}$ & $-0.04 *$ & $-0.09^{*}$ & $0.09^{*}$ & $-0.07^{*}$ & 0.00 & $0.06^{*}$ & $-0.57^{*}$ & $-0.69^{*}$ & \\
\hline
\end{tabular}

Notes: This table shows Pearson correlations (lower triangle) and Spearman rank-correlations (upper triangle) for our compound REM and AEM measures, adjusted compound REM and AEM measures as defined in Appendix B, and for

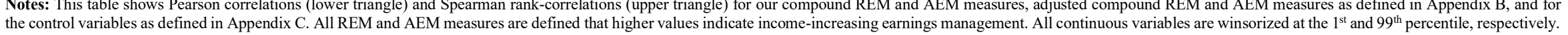
$*$ indicates two-tailed significance on the $1 \%$ level. 
TABLE 5

Univariate Results for Real Earnings Management

and Accrual-Based Earnings Management

Panel A: Real Earnings Management

\begin{tabular}{|c|c|c|c|c|c|c|}
\hline & Mean & $\begin{array}{l}\text { Standard } \\
\text { deviation }\end{array}$ & $\begin{array}{c}\text { Lower } \\
\text { quartile }\end{array}$ & Median & $\begin{array}{c}\text { Upper } \\
\text { quartile }\end{array}$ & $\begin{array}{c}\text { Firm- } \\
\text { Quarters }\end{array}$ \\
\hline \multicolumn{7}{|l|}{$R E M_{i t}$} \\
\hline Expect interval & $\begin{array}{c}-1.886 \\
(2.68)^{* * *}\end{array}$ & 11.712 & -7.390 & $\begin{array}{c}-1.372 \\
(0.40)\end{array}$ & 3.954 & 2,270 \\
\hline Effective interval & $\begin{array}{r}-0.882 \\
(1.28)\end{array}$ & 11.382 & -6.657 & $\begin{array}{l}-0.885 \\
(2.13)^{* *}\end{array}$ & 4.487 & 2,110 \\
\hline Control period & -1.214 & 11.157 & -7.189 & -1.249 & 4.334 & 16,841 \\
\hline \multicolumn{7}{|l|}{$R E M_{i t}^{\text {adj }}$} \\
\hline Expect interval & $\begin{array}{c}-0.869 \\
(3.91)^{* * *}\end{array}$ & 11.711 & -6.395 & $\begin{array}{c}-0.286 \\
(1.25)\end{array}$ & 4.935 & 2,270 \\
\hline Effective interval & $\begin{array}{l}0.045 \\
(0.26)\end{array}$ & 11.378 & -5.757 & $\begin{array}{l}0.002 \\
(0.09)\end{array}$ & 5.438 & 2,110 \\
\hline Control period & 0.111 & 11.146 & -5.865 & 0.046 & 5.610 & 16,841 \\
\hline \multicolumn{7}{|l|}{$\operatorname{PROD}_{i t}$} \\
\hline Expect interval & $\begin{array}{c}13.398 \\
(3.75)^{* * *}\end{array}$ & 12.603 & 4.738 & $\begin{array}{c}9.453 \\
(4.60)^{* * *}\end{array}$ & 17.749 & 2,270 \\
\hline Effective interval & $\begin{array}{c}13.126 \\
(4.53)^{* * *}\end{array}$ & 12.313 & 4.347 & $\begin{array}{c}9.504 \\
(3.69)^{* * *}\end{array}$ & 17.668 & 2,110 \\
\hline Control period & 14.513 & 13.383 & 5.162 & 10.585 & 19.275 & 16,841 \\
\hline \multicolumn{7}{|l|}{$A P R O D_{i t}$} \\
\hline Expect interval & $\begin{array}{c}-0.485 \\
(1.12)\end{array}$ & 4.696 & -3.008 & $\begin{array}{l}-\mathbf{0 . 7 3 7} \\
(\mathbf{1 . 6 6})^{*}\end{array}$ & 1.653 & 2,270 \\
\hline Effective interval & $\begin{array}{c}-0.333 \\
(2.46)^{* *}\end{array}$ & 4.704 & -3.026 & $\begin{array}{c}-0.683 \\
(2.82)^{* * *}\end{array}$ & 1.948 & 2,110 \\
\hline Control period & -0.604 & 4.769 & -3.373 & -0.923 & 1.753 & 16,841 \\
\hline \multicolumn{7}{|l|}{$R D_{i t}$} \\
\hline Expect interval & $\begin{array}{c}2.338 \\
(2.82)^{* * * *}\end{array}$ & 2.689 & 0.438 & $\begin{array}{l}1.451 \\
(0.80)\end{array}$ & 3.253 & 2,270 \\
\hline Effective interval & $\begin{array}{l}2.260 \\
(1.37)\end{array}$ & 2.470 & 0.495 & $\begin{array}{l}1.464 \\
(0.41)\end{array}$ & 3.200 & 2,110 \\
\hline Control period & 2.183 & 2.418 & 0.472 & 1.482 & 2.968 & 16,841 \\
\hline \multicolumn{7}{|l|}{$\boldsymbol{A R D _ { i t }} \times(-1)$} \\
\hline Expect interval & $\begin{array}{c}-0.569 \\
(3.44)^{* * *}\end{array}$ & 2.609 & -1.373 & $\begin{array}{l}0.000 \\
(0.11)\end{array}$ & 0.536 & 2,270 \\
\hline Effective interval & $\begin{array}{c}-0.474 \\
(1.66)^{*}\end{array}$ & 2.462 & -1.279 & $\begin{array}{c}-0.082 \\
(2.73)^{* * *}\end{array}$ & 0.467 & 2,110 \\
\hline Control period & -0.382 & 2.404 & -1.311 & 0.000 & 0.613 & 16,841 \\
\hline \multicolumn{7}{|l|}{$S G A_{i t}$} \\
\hline Expect interval & $\begin{array}{c}9.709 \\
(2.57)^{* * *}\end{array}$ & 8.299 & 4.051 & $\begin{array}{c}6.896 \\
(2.05)^{* *}\end{array}$ & 12.599 & 2,270 \\
\hline Effective interval & $\begin{array}{l}9.101 \\
(1.09)\end{array}$ & 7.623 & 4.114 & $\begin{array}{c}6.539 \\
(4.20)^{* * *}\end{array}$ & 11.863 & 2,110 \\
\hline Control period & 9.284 & 7.252 & 4.472 & 7.249 & 11.587 & 16,841 \\
\hline \multicolumn{7}{|l|}{$\boldsymbol{A S G A}_{i t} \times(-1)$} \\
\hline Expect interval & $\begin{array}{c}-0.862 \\
(4.62)^{* * *}\end{array}$ & 6.538 & -3.299 & $\begin{array}{l}0.147 \\
(1.12)\end{array}$ & 2.224 & 2,270 \\
\hline Effective interval & $\begin{array}{r}-0.138 \\
(0.80)\end{array}$ & 6.259 & -2.610 & $\begin{array}{c}-0.131 \\
(1.98)^{* *}\end{array}$ & 2.539 & 2,110 \\
\hline Control period & -0.248 & 5.865 & -2.945 & 0.044 & 2.417 & 16,841 \\
\hline
\end{tabular}


TABLE 5 (continued)

Panel B: Accrual-Based Earnings Management

\begin{tabular}{|c|c|c|c|c|c|c|}
\hline & Mean & $\begin{array}{l}\text { Standard } \\
\text { deviation }\end{array}$ & $\begin{array}{c}\text { Lower } \\
\text { quartile }\end{array}$ & Median & $\begin{array}{c}\text { Upper } \\
\text { quartile }\end{array}$ & $\begin{array}{c}\text { Firm- } \\
\text { Quarters }\end{array}$ \\
\hline \multicolumn{7}{|l|}{$A E M_{i t}$} \\
\hline Expect interval & $\begin{array}{c}1.089 \\
(7.68)^{* * * *}\end{array}$ & 6.770 & -1.997 & $\begin{array}{c}0.099 \\
(4.79)^{* * *}\end{array}$ & 2.960 & 2,270 \\
\hline Effective interval & $\begin{array}{c}-0.175 \\
(2.02)^{* *}\end{array}$ & 5.327 & -2.334 & $\begin{array}{c}-0.488 \\
(2.95)^{* * *}\end{array}$ & 1.609 & 2,110 \\
\hline Control period & 0.089 & 5.682 & -2.208 & -0.244 & 1.958 & 16,841 \\
\hline \multicolumn{7}{|l|}{$A E M_{i t}^{\text {adj }}$} \\
\hline Expect interval & $\begin{array}{c}0.798 \\
(6.49)^{* * *}\end{array}$ & 6.770 & -2.274 & $\begin{array}{c}-0.129 \\
(3.04)^{* * *}\end{array}$ & 2.582 & 2,270 \\
\hline Effective interval & $\begin{array}{c}-0.512 \\
(3.61)^{* * *}\end{array}$ & 5.327 & -2.606 & $\begin{array}{c}-0.840 \\
(3.00)^{* * *}\end{array}$ & 1.266 & 2,110 \\
\hline Control period & -0.043 & 5.651 & -2.324 & -0.382 & 1.791 & 16,841 \\
\hline \multicolumn{7}{|l|}{$T A C_{i t}$} \\
\hline Expect interval & $\begin{array}{c}-2.110 \\
(3.43)^{* * *}\end{array}$ & 4.806 & -3.776 & $\begin{array}{c}-1.642 \\
(2.37)^{* * *}\end{array}$ & 0.051 & 2,270 \\
\hline Effective interval & $\begin{array}{c}-1.795 \\
(0.34)\end{array}$ & 4.274 & -3.318 & $\begin{array}{l}-1.406 \\
(0.60)\end{array}$ & 0.071 & 2,110 \\
\hline Control period & -1.759 & 4.557 & -3.288 & -1.468 & 0.159 & 16,841 \\
\hline \multicolumn{7}{|l|}{$A N C A_{i t}$} \\
\hline Expect interval & $\begin{array}{l}0.197 \\
(1.25)\end{array}$ & 4.746 & -1.608 & $\begin{array}{l}0.104 \\
(1.52)\end{array}$ & 1.936 & 2,270 \\
\hline Effective interval & $\begin{array}{l}0.111 \\
(0.39)\end{array}$ & 4.199 & -1.443 & $\begin{array}{l}0.055 \\
(0.74)\end{array}$ & 1.596 & 2,110 \\
\hline Control period & 0.072 & 4.408 & -1.683 & 0.017 & 1.742 & 16,841 \\
\hline \multicolumn{7}{|l|}{$A C A_{i t}$} \\
\hline Expect interval & $\begin{array}{c}0.911 \\
(7.95)^{* * *}\end{array}$ & 5.957 & -1.774 & $\begin{array}{c}-0.143 \\
(2.55)^{* *}\end{array}$ & 2.168 & 2,270 \\
\hline Effective interval & $\begin{array}{c}-0.322 \\
(3.23)^{* * * *}\end{array}$ & 4.884 & -2.022 & $\begin{array}{c}-\mathbf{0 . 5 8 0} \\
(\mathbf{5 . 3 1})^{* * *}\end{array}$ & 0.920 & 2,110 \\
\hline Control period & 0.035 & 4.774 & -1.603 & -0.285 & 1.235 & 16,841 \\
\hline
\end{tabular}

Notes: Panel A shows univariate results for our compound REM measure, adjusted compound REM measure, REM components, and underlying unadjusted variables (in percent). Panel A shows univariate results for our compound AEM measure, adjusted AEM measure, and total accruals. All REM and AEM measures are defined that higher values indicate income-increasing earnings management. Panel B shows univariate results for our compound AEM measure, adjusted AEM measure, its components, and underlying unadjusted variables, as defined in Appendix B. In mean equality tests relative to the control period, $*{ }^{* *}$, and $* * *$ indicate two-tailed significance on the $10 \%, 5 \%$, and $1 \%$ level, respectively. 
TABLE 6

Regression Results for Real Earnings Management and Accrual-Based Earnings Management

\begin{tabular}{|c|c|c|c|c|c|c|c|c|c|}
\hline & & \multicolumn{4}{|c|}{ Full Sample } & \multicolumn{4}{|c|}{ Full Sample with $E X P_{t}=E X P_{t}^{\text {incentive }}$} \\
\hline & & \multirow{2}{*}{\multicolumn{2}{|c|}{$\begin{array}{c}\text { Column (1) } \\
\text { Real Earnings } \\
\text { Management } \\
\left(\text { REM } M_{i t}\right)\end{array}$}} & \multirow{2}{*}{\multicolumn{2}{|c|}{$\begin{array}{c}\text { Column (2) } \\
\text { Accrual-Based } \\
\text { Earnings } \\
\text { Management }\left(A E M_{i t}\right)\end{array}$}} & \multirow{2}{*}{\multicolumn{2}{|c|}{$\begin{array}{c}\text { Column (3) } \\
\text { Real Earnings } \\
\text { Management } \\
\left(R E M_{i t}\right)\end{array}$}} & \multirow{2}{*}{\multicolumn{2}{|c|}{$\begin{array}{c}\text { Column (4) } \\
\text { Accrual-Based } \\
\text { Earnings } \\
\text { Management }\left(A E M_{i t}\right)\end{array}$}} \\
\hline & & & & & & & & & \\
\hline & & Coeff. & Sig. & Coeff. & Sig. & Coeff. & Sig. & Coeff. & Sig. \\
\hline$E X P_{t}$ & $-\left(\mathrm{H} 1, \beta_{1}\right)$ & -0.841 & $(6.44)^{* * *}$ & & & -7.104 & $(6.97)^{* * *}$ & & \\
\hline$E F F_{t}$ & $+\left(\mathrm{H} 1, \beta_{2}\right)$ & 0.505 & $(\mathbf{3 . 5 2})^{* * *}$ & & & 0.537 & $(\mathbf{3 . 8 5})^{* * *}$ & & \\
\hline$E X P_{t}$ & $+\left(\mathrm{H} 2, \beta_{1}\right)$ & & & 0.668 & $(5.76)^{* * *}$ & & & 5.761 & $(6.36)^{* * *}$ \\
\hline$E F F_{t}$ & $-\left(\mathrm{H} 2, \beta_{2}\right)$ & & & -0.463 & $(3.40)^{* * *}$ & & & -0.484 & $(3.61)^{* * *}$ \\
\hline$T R E N D_{t}$ & & 0.025 & $(2.98)^{* * *}$ & -0.020 & $(2.70)^{* * *}$ & 0.026 & $(3.04)^{* * *}$ & -0.021 & $(2.81)^{* * *}$ \\
\hline$S H A R E_{i t-1}$ & & 5.941 & $(1.04)$ & -3.765 & $(0.64)$ & 5.642 & $(0.98)$ & -3.497 & $(0.60)$ \\
\hline$Z_{S C O R E} E_{i t-1}$ & & 0.013 & $(0.91)$ & -0.019 & $(1.58)$ & 0.013 & $(0.90)$ & -0.019 & $(1.57)$ \\
\hline$I N S T_{i t-1}$ & & -0.030 & $(0.07)$ & -0.127 & $(0.30)$ & -0.032 & $(0.07)$ & -0.124 & $(0.29)$ \\
\hline BIGFOUR $_{i t}$ & & 0.089 & $(0.21)$ & 0.025 & $(0.07)$ & 0.086 & $(0.20)$ & 0.027 & $(0.07)$ \\
\hline$T E N U R E_{i t}$ & & -0.016 & $(0.65)$ & 0.007 & $(0.35)$ & -0.016 & $(0.68)$ & 0.008 & $(0.38)$ \\
\hline$C Y C L E_{i t-1}$ & & -0.007 & $(6.10)^{* * *}$ & 0.006 & $(6.61)^{* * *}$ & -0.007 & $(6.10)^{* * *}$ & 0.006 & $(6.61)^{* * *}$ \\
\hline$N O A_{i t-1}$ & & 0.765 & $(3.40)^{* * *}$ & -0.847 & $(5.72)^{* * *}$ & 0.757 & $(3.94)^{* * *}$ & -0.839 & $(5.66)^{* * *}$ \\
\hline$R O A_{i t}$ & & 0.295 & $(10.57)^{* * *}$ & 0.671 & $(27.15)^{* * *}$ & 0.295 & $(10.56)^{* * *}$ & 0.672 & $(27.16)^{* * *}$ \\
\hline$M T B_{i t}$ & & -0.000 & $(0.01)$ & 0.002 & $(0.23)$ & -0.000 & $(0.03)$ & 0.002 & $(0.25)$ \\
\hline $\operatorname{ASSETS}_{i t}$ & & 0.088 & $(0.43)$ & -0.107 & $(0.61)$ & 0.107 & $(0.52)$ & -0.124 & $(0.71)$ \\
\hline$E A R N_{i t}$ & & -0.427 & $(37.03)^{* * *}$ & -0.504 & $(44.25)^{* * *}$ & -0.427 & $(37.08)^{* * *}$ & -0.504 & $(44.27)^{* * *}$ \\
\hline
\end{tabular}

\begin{tabular}{clc}
\multicolumn{2}{c}{ Calendar Year End Firms Only } \\
\hline Column (5) & & Column (6) \\
\cline { 1 - 1 } $\begin{array}{c}\text { Real Earnings } \\
\text { Management } \\
\left(R E M_{i t}\right)\end{array}$ & & $\begin{array}{c}\text { Accrual-Based } \\
\text { Earnings } \\
\text { Management }\left(A E M_{i t}\right)\end{array}$ \\
\hline Coeff. $\quad$ Sig. & Coeff. Sig. \\
\hline
\end{tabular}

\section{$-1.068(7.04)^{* * * *}$}

$0.881(4.29)^{* * *}$

\begin{tabular}{rlrl} 
& & $\mathbf{0 . 8 9 7}$ & $\mathbf{( 6 . 7 1 )}^{* * *}$ \\
& & $-\mathbf{0 . 9 7 8}$ & $(\mathbf{5 . 3 9})^{* * *}$ \\
0.030 & $(3.26)^{* * *}$ & -0.024 & $(2.81)^{* * *}$ \\
& & & \\
0.859 & $(0.14)$ & 0.429 & $(0.07)$ \\
0.011 & $(0.69)$ & -0.014 & $(1.03)$ \\
-0.252 & $(0.53)$ & -0.007 & $(0.01)$ \\
-0.110 & $(0.20)$ & 0.208 & $(0.50)$ \\
-0.031 & $(1.13)$ & 0.024 & $(0.97)$ \\
-0.005 & $(4.11)^{* * *}$ & 0.004 & $(4.81)^{* * *}$ \\
0.638 & $(3.52)^{* * *}$ & -0.691 & $(4.67)^{* * *}$ \\
0.329 & $(9.96)^{* * *}$ & 0.648 & $(22.18)^{* * *}$ \\
0.002 & $(0.25)$ & 0.002 & $(0.23)$ \\
0.410 & $(2.00)^{* *}$ & -0.377 & $(2.06)^{* *}$ \\
-0.417 & $(32.17)^{* * *}$ & -0.503 & $(37.31)^{* * *}$ \\
& & & \\
\hline
\end{tabular}


TABLE 6 (continued)

\begin{tabular}{|c|c|c|c|c|c|c|c|c|c|c|c|c|}
\hline \multirow[b]{2}{*}{$E C O N_{t}^{\text {growth }}$} & \multicolumn{2}{|c|}{ Column (1) } & \multicolumn{2}{|c|}{ Column (2) } & \multicolumn{2}{|c|}{ Column (3) } & \multicolumn{2}{|c|}{ Column (4) } & \multicolumn{2}{|c|}{ Column (5) } & \multicolumn{2}{|c|}{ Column (6) } \\
\hline & 0.013 & $(0.21)$ & 0.107 & $(1.76)^{*}$ & 0.002 & $(0.03)$ & 0.116 & $(1.92)^{*}$ & 0.025 & $(0.33)$ & 0.115 & $(1.80)^{*}$ \\
\hline $\operatorname{ECON}_{t}^{\mathrm{ret}}$ & 0.014 & $(3.72)^{* * *}$ & -0.011 & $(3.15)^{* * *}$ & 0.016 & $(4.23)^{* * *}$ & -0.013 & $(3.57)^{* * *}$ & 0.028 & $(5.23)^{* * *}$ & -0.030 & $(5.95)^{* * *}$ \\
\hline $\operatorname{ECON}_{t}^{\mathrm{vol}}$ & -0.002 & $(1.80)^{*}$ & 0.001 & (1.12) & -0.002 & $(1.57)$ & 0.001 & $(0.92)$ & -0.000 & $(0.07)$ & -0.001 & $(0.55)$ \\
\hline Fixed Effects & \multicolumn{2}{|c|}{$\mathrm{F}, \mathrm{CQ}$, and $\mathrm{FQ}$} & \multicolumn{2}{|c|}{$\mathrm{F}, \mathrm{CQ}$, and $\mathrm{FQ}$} & \multicolumn{2}{|c|}{$\mathrm{F}, \mathrm{CQ}$, and $\mathrm{FQ}$} & \multicolumn{2}{|c|}{$\mathrm{F}, \mathrm{CQ}$, and $\mathrm{FQ}$} & \multicolumn{2}{|c|}{$\mathrm{F}, \mathrm{CQ}$, and $\mathrm{FQ}$} & \multicolumn{2}{|c|}{$\mathrm{F}, \mathrm{CQ}$, and $\mathrm{FQ}$} \\
\hline Firm-Quarters & \multicolumn{2}{|c|}{21,221} & \multicolumn{2}{|c|}{21,221} & \multicolumn{2}{|c|}{21,221} & \multicolumn{2}{|c|}{21,221} & \multicolumn{2}{|c|}{15,906} & \multicolumn{2}{|c|}{15,906} \\
\hline Firms & \multicolumn{2}{|c|}{851} & \multicolumn{2}{|c|}{851} & \multicolumn{2}{|c|}{851} & \multicolumn{2}{|c|}{851} & \multicolumn{2}{|c|}{653} & \multicolumn{2}{|c|}{653} \\
\hline Adjusted R² & \multicolumn{2}{|c|}{0.477} & \multicolumn{2}{|c|}{0.593} & \multicolumn{2}{|c|}{0.478} & \multicolumn{2}{|c|}{0.593} & \multicolumn{2}{|c|}{0.463} & \multicolumn{2}{|c|}{0.596} \\
\hline F-test for: $\beta_{1}=-\beta_{2}$ & \multicolumn{2}{|c|}{$(2.29)$} & \multicolumn{2}{|c|}{$(1.08)$} & & & & & \multicolumn{2}{|c|}{$(0.46)$} & \multicolumn{2}{|c|}{$(0.11)$} \\
\hline
\end{tabular}

Notes: This table shows the results of regression analyses for our compound REM measure $\left(R E M_{i t}\right)$ (Equation 1), defined as abnormally high production costs $\left(A P R O D_{i t}\right)$, plus abnormally low R\&D expenses $\left(A R D_{i t} \times(-1)\right)$, plus abnormally low SG\&A expenses $\left(A S G A_{i t} \times(-1)\right)$, and our compound AEM measure $\left(A E M_{i t}\right)$ (Equation 2), as defined in Appendix B (in percent). All REM and AEM measures are defined that higher values indicate income-increasing earnings management. In Column 1,2,5, and 6, the 'expect interval' $\left(E X P_{t}\right)$ is defined as the four fiscal quarters preceding the effectiveness of the $21 \%$ federal tax rate. The 'effective interval' $\left(E F F_{t}\right)$ is defined as the four fiscal quarters

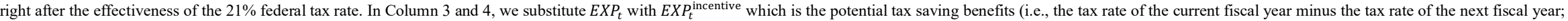
Table 2) in the 'expect interval' and zero outside the 'expect interval'. In Column 5 and 6 , the sample is restricted to the firms with the highest potential tax saving benefits (i.e., the firms with fiscal year equal to the calendar year; Table 2).

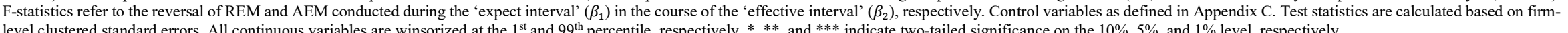


TABLE 7

Regression Results for Real Earnings Management and Accrual-Based Earnings Management

\begin{tabular}{|c|c|c|c|c|c|c|c|}
\hline \multicolumn{4}{|c|}{ Two Quarters Earnings Management Analyses } & \multicolumn{4}{|c|}{ One Quarter Earnings Management Analyses } \\
\hline \multicolumn{2}{|c|}{ Column (1) } & \multicolumn{2}{|c|}{ Column (2) } & \multicolumn{2}{|c|}{ Column (3) } & \multicolumn{2}{|c|}{ Column (4) } \\
\hline \multicolumn{2}{|c|}{$\begin{array}{l}\text { Real Earnings Management } \\
\left(\text { REM }_{i t}\right)\end{array}$} & \multicolumn{2}{|c|}{$\begin{array}{l}\text { Accrual-Based Earnings Management } \\
\qquad\left(A E M_{i t}\right)\end{array}$} & \multicolumn{2}{|c|}{$\begin{array}{l}\text { Real Earnings Management } \\
\left(R E M_{i t}\right)\end{array}$} & \multicolumn{2}{|c|}{$\begin{array}{l}\text { Accrual-Based Earnings Management } \\
\qquad\left(A E M_{i t}\right)\end{array}$} \\
\hline Coeff. & Sig. & Coeff. & Sig. & Coeff. & Sig. & Coeff. & Sig. \\
\hline
\end{tabular}

$\begin{array}{ll}E X P_{t} & -\left(\mathrm{H} 1, \beta_{1}\right) \\ E F F_{t} & +\left(\mathrm{H} 1, \beta_{2}\right) \\ E X P_{t} & +\left(\mathrm{H} 2, \beta_{1}\right) \\ E F F_{t} & -\left(\mathrm{H} 2, \beta_{2}\right)\end{array}$

$-1.565(8.67)^{* * *}$

$0.512(2.94)^{* * *}$

$0.029(3.10)^{* * *}$

$2.361 \quad(0.38)$

$0.013 \quad(0.79)$

$-0.322 \quad(0.67)$

$-0.064 \quad(0.13)$

$-0.028 \quad(1.03)$

$-0.005 \quad(4.14)^{* * *}$

$0.667 \quad(3.68)^{* * *}$

$0.333(10.03)^{* * *}$

$0.003 \quad(0.26)$

$0.338 \quad(1.68)^{*}$

$-0.418 \quad(32.23)^{* * *}$
$-1.407 \quad(6.67)^{* * *}$

$0.888(3.65)^{* * *}$

$\begin{aligned} \mathbf{1 . 3 2 4} & (\mathbf{7 . 8 2})^{* * *} \\ \mathbf{- 0 . 4 3 2} & (\mathbf{3 . 2 3})^{* * *} \\ -0.023 & (2.82)^{* * *} \\ & \\ -1.075 & (0.17) \\ -0.016 & (1.13) \\ 0.070 & (0.15) \\ 0.174 & (0.42) \\ 0.021 & (0.85) \\ 0.004 & (4.85)^{* * *} \\ -0.717 & (4.81)^{* * *} \\ 0.645 & (21.88)^{* * *} \\ 0.002 & (0.23) \\ -0.310 & (1.73)^{*} \\ -0.502 & (37.25)^{* * *}\end{aligned}$

$1.167 \quad(5.61)^{* * *}$

$-0.740 \quad(4.47)^{* * *}$

$-0.018 \quad(2.22)^{* *}$

$-2.106 \quad(0.34)$

$-0.016 \quad(1.15)$

$-0.010 \quad(0.02)$

$0.164 \quad(0.40)$

$0.020 \quad(0.79)$

$0.004 \quad(4.84)^{* * *}$

$-0.746 \quad(5.03)^{* * *}$

$0.645(21.91)^{* * *}$

$0.002 \quad(0.23)$

$-0.242 \quad(1.36)$

$-0.503 \quad(37.22)^{* * *}$ 
TABLE 7 (continued)

Column (1)

$\begin{array}{lcl}\operatorname{ECON}_{t}^{\text {growth }} & 0.109 & (1.45) \\ \operatorname{CON}_{t}^{\text {ret }} & 0.016 & (4.15)^{* * *} \\ \operatorname{CON}_{t}^{\text {vol }} & -0.002 & (1.37) \\ & & \\ \text { Fixed Effects } & \mathrm{F}, \mathrm{CQ}, \text { and FQ }\end{array}$

Firm-Quarters

Firms

Adjusted $\mathrm{R}^{2}$

F-test for: $\beta_{1}=-\beta_{2}$
Column (2)

\begin{aligned} & 0.014$(0.22) \\ &-0.016(4.28)^{* * *} \\ & 0.001(1.04) \\ & \\ &$\hline F, CQ, and FQ \end{aligned}

15,906

653

0.595

(16.21)
Column (3)

\begin{aligned} & 0.119$(1.56) \\ & 0.012(3.43)^{* * *} \\ &-0.003(1.90)^{*} \\ & \\ &$\hline\end{aligned}

F, CQ, and FQ

15,906

653

0.460

(2.40)
Column (4)

$0.005 \quad(0.08)$

$-0.012 \quad(3.53)^{* * *}$

$0.002 \quad(1.52)$

F, CQ, and FQ

15,906

653

0.593

(2.45)

Notes: This table shows the results of regression analyses for our compound REM measure $\left(R E M_{i t}\right)$ (Equation 1), defined as abnormal production costs $\left(A P R O D_{i t}\right)$, plus abnormally low R\&D expenses $\left.\left(A R D_{i t}\right) \times(-1)\right)$, plus abnormally low SG\&A expenses $\left(A S G A_{i t} \times(-1)\right)$, and our compound AEM measure $\left(A E M_{i t}\right)$ (Equation 2), as defined in Appendix B. All REM and AEM measures are defined that higher values indicate income-increasing earnings management. In Column 1 and 2, the 'expect interval' $\left(E X P_{t}\right)$ is defined as the two fiscal quarters preceding the effectiveness of the $21 \%$ federal tax rate. The 'effective interval' $\left(E F F_{t}\right)$ is defined as the two fiscal quarters right after the effectiveness of the $21 \%$ federal tax rate. In Column 3 and 4 , the 'expect interval' $\left(E X P_{t}\right)$ is defined as the fiscal quarter preceding the effectiveness of the $21 \%$ federal tax rate. The 'effective interval' $\left(E F F_{t}\right)$ is defined as the fiscal quarter right after the effectiveness of the $21 \%$ federal tax rate. F-statistics refer to the reversal of REM and AEM conducted during the 'expect interval' $\left(\beta_{1}\right)$ in the course of the 'effective interval' $\left(\beta_{2}\right)$, respectively. Control variables as defined in Appendix C. Test statistics are calculated based on firm-level clustered standard errors. All continuous variables are winsorized at the $1^{\text {st }}$ and $99^{\text {th }}$ percentile, respectively. *, **, and *** indicate two-tailed significance on the $10 \%$, $5 \%$, and $1 \%$ level, respectively. 
TABLE 8

Regression Results for Accrual-Based Earnings Management of Firms with Financial Reporting Pressure

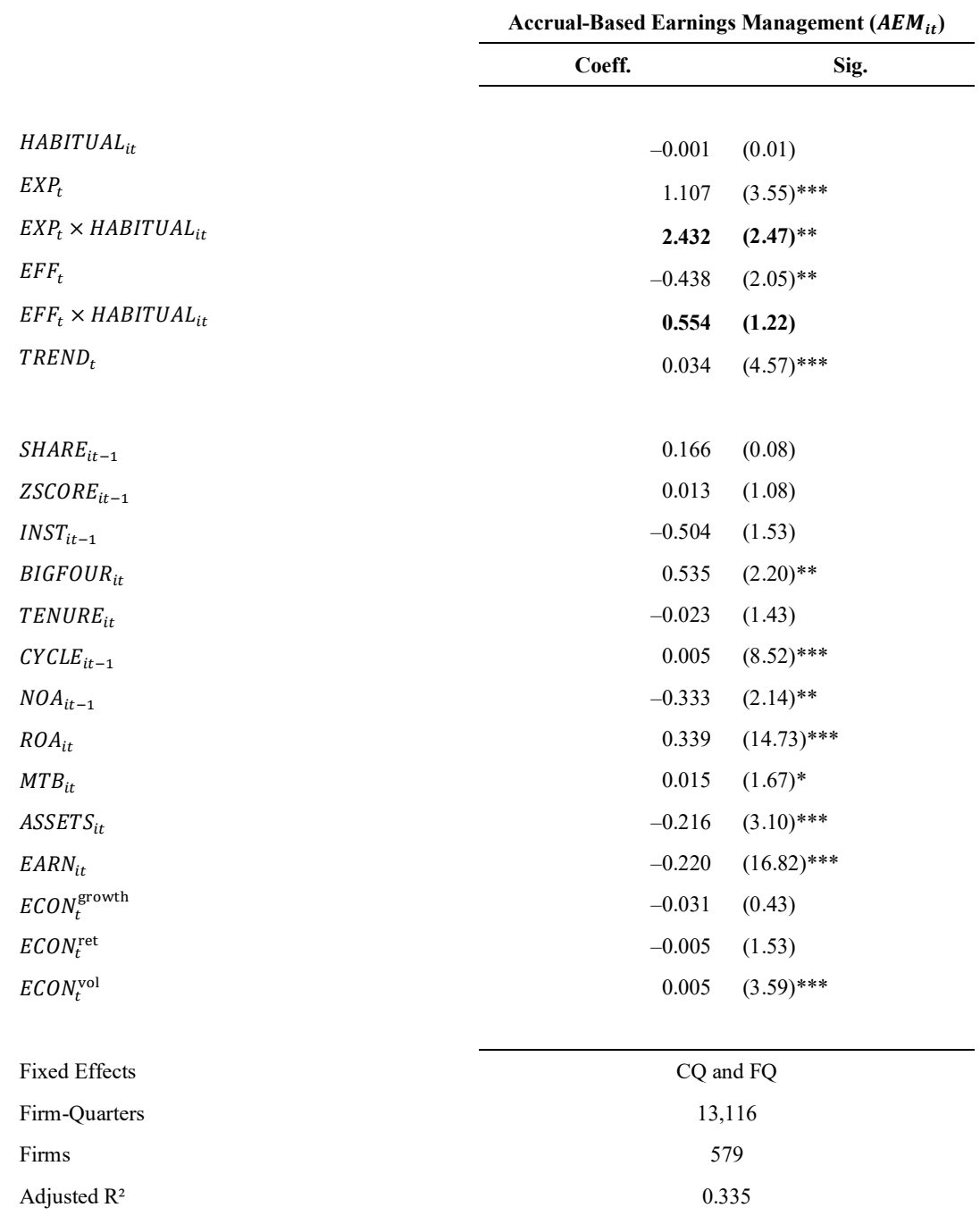

Notes: This table shows the results of a regression analysis of our compound AEM measure $\left(A E M_{i t}\right)$ as defined in Appendix B. The 'expect interval' $\left(E X P_{t}\right)$ is defined as the four fiscal quarters preceding the effectiveness of the $21 \%$ federal tax rate. The 'effective interval' $\left(E F F_{t}\right)$ is defined as the four fiscal quarters right after the effectiveness of the $21 \%$ federal tax rate. HABITUAL it is an indicator that takes a value of 1 if the firm is a "habitual earnings target beater" as defined in Appendix C. Control variables as defined in Appendix C. The sample is restricted to the firms with the highest potential tax saving benefits (i.e., the firms with fiscal year equal to the calendar year; Table 2). Test statistics are calculated based on firm-level clustered standard errors. All continuous variables are winsorized at the $1^{\text {st }}$ and $99^{\text {th }}$ percentile, respectively. $* * *$, and *** indicate two-tailed significance on the $10 \%, 5 \%$, and $1 \%$ level, respectively. 
TABLE 9

Regression Results for Current and Non-Current Accruals Manipulations

\begin{tabular}{|c|c|c|c|c|c|}
\hline & \multirow[b]{3}{*}{ Predicted Sign } & \multicolumn{2}{|c|}{ Column (1) } & \multicolumn{2}{|c|}{ Column (2) } \\
\hline & & \multicolumn{2}{|c|}{$\begin{array}{l}\text { Abnormal Current Accruals } \\
\qquad\left(A C A_{i t}\right)\end{array}$} & \multicolumn{2}{|c|}{$\begin{array}{l}\text { Abnormal Non-Current Accruals } \\
\qquad\left(A N C A_{i t}\right)\end{array}$} \\
\hline & & Coeff. & Sig. & Coeff. & Sig. \\
\hline$E X P_{t}$ & $+\left(\mathrm{H} 2, \beta_{1}\right)$ & -0.015 & (0.14) & 0.964 & $(6.31)^{* * *}$ \\
\hline$E F F_{t}$ & $-\left(\mathrm{H} 2, \beta_{2}\right)$ & -0.303 & $(2.03)^{* *}$ & -0.657 & $(3.81)^{* * *}$ \\
\hline $\operatorname{TREND}_{t}$ & & -0.012 & $(1.98)^{* *}$ & -0.009 & $(1.21)$ \\
\hline$S H A R E_{i t-1}$ & & 5.575 & $(1.12)$ & -2.786 & $(0.48)$ \\
\hline$Z S C O R E_{i t-1}$ & & -0.005 & $(0.43)$ & -0.010 & $(0.90)$ \\
\hline$I N S T_{i t-1}$ & & 0.136 & $(0.44)$ & -0.210 & $(0.58)$ \\
\hline BIGFOUR $_{i t}$ & & -0.177 & $(0.55)$ & 0.465 & (1.29) \\
\hline TENURE $E_{i t}$ & & 0.031 & $(1.92)^{*}$ & -0.007 & $(0.32)$ \\
\hline$C Y C L E_{i t-1}$ & & -0.000 & $(0.42)$ & 0.004 & $(4.49)^{* * *}$ \\
\hline$N O A_{i t-1}$ & & -0.703 & $(4.35)^{* * *}$ & 0.063 & $(0.35)$ \\
\hline$R O A_{i t}$ & & 0.218 & $(10.18)^{* * *}$ & 0.410 & $(14.90)^{* * *}$ \\
\hline$M T B_{i t}$ & & 0.004 & $(0.57)$ & -0.005 & $(0.66)$ \\
\hline ASSETS $_{i t}$ & & 0.073 & $(0.55)$ & -0.399 & $(2.51)^{* *}$ \\
\hline$E A R N_{i t}$ & & -0.248 & $(23.63)^{* * *}$ & -0.240 & $(18.31)^{* * *}$ \\
\hline$E C O N_{t}^{\text {growth }}$ & & -0.048 & $(0.63)$ & 0.112 & (1.49) \\
\hline$E \operatorname{CON}_{t}^{\mathrm{ret}}$ & & -0.016 & $(3.81)^{* * *}$ & -0.014 & $(3.18)^{* * *}$ \\
\hline $\operatorname{CCON}_{t}^{\mathrm{vol}}$ & & 0.000 & $(0.19)$ & -0.000 & $(0.17)$ \\
\hline Fixed Effects & & $\mathrm{F}, \mathrm{CQ}$ & ind FQ & $\mathrm{F}, \mathrm{CQ}$, & nd FQ \\
\hline Firm-Quarters & & & & 15 , & \\
\hline Firms & & & & 6 & \\
\hline Adjusted R ${ }^{2}$ & & & & 0.2 & \\
\hline F-test for: $\beta_{1}=-\beta_{2}$ & & & & & \\
\hline
\end{tabular}

Notes: This table shows the results of regression analyses of the components of AEM (Equation 1), i.e., abnormal current accruals $\left(A C A_{i t}\right)$ and abnormal non-current accruals $\left(A N C A_{i t}\right)$, as defined in Appendix B. The 'expect interval' $\left(E X P_{t}\right)$ is defined as the four fiscal quarters preceding the effectiveness of the $21 \%$ federal tax rate. The 'effective interval' $\left(E F F_{t}\right)$ is defined as the four fiscal quarters right after the effectiveness of the $21 \%$ federal tax rate. Control variables as defined in Appendix C. The sample is restricted to the firms with the highest potential tax saving benefits (i.e., the firms with fiscal year equal to the calendar year; Table 2). Test statistics are calculated based on firm-level clustered standard errors. All continuous variables are winsorized at the $1^{\text {st }}$ and $99^{\text {th }}$ percentile, respectively. $*$, **, and $* * *$ indicate two-tailed significance on the $10 \%, 5 \%$, and $1 \%$ level, respectively. 
TABLE 10

Regression Results for the Components of Real Earnings Management

\begin{tabular}{|c|c|c|c|c|c|c|c|}
\hline & \multirow[b]{3}{*}{ Predicted Sign } & \multicolumn{2}{|c|}{ Column (1) } & \multicolumn{2}{|c|}{ Column (2) } & \multicolumn{2}{|c|}{ Column (3) } \\
\hline & & \multicolumn{2}{|c|}{$\begin{array}{c}\text { Abnormally High } \\
\text { Production Costs } \\
\left(A P R O D_{i t}\right)\end{array}$} & \multicolumn{2}{|c|}{$\begin{array}{l}\text { Abnormally Low } \\
\text { R\&D Expenses } \\
\left(A R D_{i t} \times(-1)\right)\end{array}$} & \multicolumn{2}{|c|}{$\begin{array}{l}\text { Abnormally Low } \\
\text { SG\&A Expenses } \\
\left(A S G A_{i t} \times(-1)\right)\end{array}$} \\
\hline & & Coeff. & Sig. & Coeff. & Sig. & Coeff. & Sig. \\
\hline$E X P_{t}$ & $-\left(\mathrm{H} 1, \beta_{1}\right)$ & -0.209 & $(2.90)^{* * *}$ & -0.128 & $(2.97)^{* * *}$ & -0.688 & $(7.04)^{* * *}$ \\
\hline$E F F_{t}$ & $+\left(\mathrm{H} 1, \beta_{2}\right)$ & 0.522 & $(4.62)^{* * *}$ & 0.117 & $(1.75)^{*}$ & 0.175 & (1.53) \\
\hline$T_{R E N D_{t}}$ & & 0.007 & (1.37) & -0.003 & $(1.03)$ & 0.024 & $(4.03)^{* * *}$ \\
\hline$S H A R E_{i t-1}$ & & -14.020 & $(2.73)^{* * *}$ & 2.512 & $(1.02)$ & 12.120 & $(2.61)^{* * *}$ \\
\hline$Z S C O R E_{i t-1}$ & & 0.000 & $(0.05)$ & -0.014 & $(2.33)^{* *}$ & 0.010 & $(0.92)$ \\
\hline$I N S T_{i t-1}$ & & -0.574 & $(2.23)^{* *}$ & -0.011 & $(0.07)$ & 0.343 & (1.18) \\
\hline$B_{\text {BIFOUR }}$ & & 0.337 & $(1.51)$ & -0.241 & $(1.37)$ & -0.167 & $(0.49)$ \\
\hline$T_{E N U R E_{i t}}$ & & -0.003 & $(0.24)$ & -0.008 & $(0.96)$ & -0.015 & $(0.83)$ \\
\hline$C Y C L E_{i t-1}$ & & -0.002 & $(2.96)^{* * *}$ & -0.000 & $(0.22)$ & -0.003 & $(4.39)^{* * *}$ \\
\hline$N O A_{i t-1}$ & & 0.145 & (1.38) & 0.163 & $(2.56)^{* *}$ & 0.353 & $(2.91)^{* * *}$ \\
\hline$R O A_{i t}$ & & -0.064 & $(4.55)^{* * *}$ & 0.090 & $(8.66)^{* * *}$ & 0.273 & $(14.10)^{* * *}$ \\
\hline$M T B_{i t}$ & & 0.003 & $(0.88)$ & -0.004 & $(1.12)$ & -0.000 & $(0.06)$ \\
\hline ASSETS $_{i t}$ & & 0.219 & $(1.80)^{*}$ & 0.053 & $(0.65)$ & 0.142 & (1.04) \\
\hline$E A R N_{i t}$ & & -0.160 & $(18.49)^{* * *}$ & -0.056 & $(14.41)^{* * *}$ & -0.165 & $(20.94)^{* * *}$ \\
\hline$E C O N_{t}^{\text {growth }}$ & & -0.004 & $(0.07)$ & 0.030 & $(1.02)$ & -0.021 & $(0.43)$ \\
\hline $\operatorname{CCON}_{t}^{\mathrm{ret}}$ & & 0.013 & $(4.06)^{* * *}$ & 0.005 & $(2.75)^{* * *}$ & 0.011 & $(3.31)^{* * *}$ \\
\hline$E \operatorname{CON}_{t}^{\mathrm{vol}}$ & & 0.004 & $(4.13)^{* * *}$ & -0.002 & $(3.54)^{* * *}$ & -0.003 & $(2.63)^{* * *}$ \\
\hline Fixed Effects & & $\mathrm{F}, \mathrm{CQ}$, & ind FQ & $\mathrm{F}, \mathrm{CQ}$, & and $\mathrm{FQ}$ & $\mathrm{F}, \mathrm{CQ}$, & and FQ \\
\hline Firm-Quarters & & 15 , & & & & & 06 \\
\hline Firms & & 6 & & & & & \\
\hline Adjusted $\mathrm{R}^{2}$ & & 0.2 & & & & & 37 \\
\hline F-test for: $\beta_{1}=-\beta_{2}$ & & (4. & & & & & 16) \\
\hline
\end{tabular}

Notes: This table shows the results of regression analyses of the components of REM (Equation 1), i.e., abnormally high production costs $\left(A P R O D_{i t}\right)$, abnormally low R\&D expenses $\left(A R D_{i t} \times(-1)\right)$, and abnormally low SG\&A expenses $\left(A S G A_{i t} \times(-1)\right)$ as defined in Appendix B. All REM measures are defined that higher values indicate income-increasing earnings management. The 'expect interval' $\left(E X P_{t}\right)$ is defined as the four fiscal quarters preceding the effectiveness of the $21 \%$ federal tax rate. The 'effective interval' $\left(E F F_{t}\right)$ is defined as the four fiscal quarters right after the effectiveness of the $21 \%$ federal tax rate. Control variables as defined in Appendix C. The sample is restricted to the firms with the highest potential tax saving benefits (i.e., the firms with fiscal year equal to the calendar year; Table 2). Test statistics are calculated based on firm-level clustered standard errors. All continuous variables are winsorized at the $1^{\text {st }}$ and $99^{\text {th }}$ percentile, respectively. ${ }^{*}, * *$, and $* * *$ indicate two-tailed significance on the $10 \%, 5 \%$, and $1 \%$ level, respectively. 